\title{
ENTRE AS IMUNIDADES E A RESPONSABILIDADE DAS ORGANIZAÇÕES INTERNACIONAIS: POSSÍVEIS CONTORNOS PARA UMA EFETIVA REPARAÇÃO
}

\section{BETWEEN IMMUNITIES AND THE RESPONSIBILITY OF INTERNATIONAL ORGANIZATIONS: POSSIBLE OUTLINES FOR AN EFFECTIVE REMEDY}

\author{
${ }^{1}$ Tatiana de Almeida Freitas Rodrigues Cardoso
}

\section{RESUMO}

O presente artigo tem como objetivo debater novas possibilidades de responsabilização das organizações internacionais, afastando-se os privilégios e imunidades normalmente a elas atribuídos, os quais impedem a adoção de justas reparações em favor daqueles que sofreram prejuízos por seus atos e omissões quando executando as suas atividades-fim. Para tanto, em um primeiro momento, almeja-se (1) explicar porque as organizações internacionais podem atuar no plano internacional, bem como (2) pontuar os tipos de benefícios que esses organismos ostentam em direito internacional. Ato contínuo, pretende-se na sequência (3) detalhar a responsabilidade internacional das organizações, exibindo-se os requisitos para se atribuir um ato ilícito à uma entidade, como também (4) delinear as hipóteses para se afastar as imunidades das mesmas pela violação de uma regra de direito internacional. Ao cabo, conclui-se que na inexistência de um mecanismo para solução de litígios no ambiente orgânico das organizações e no caso delas ultrapassarem os limites de suas funções, a imunidade poderia ser afastada momento em que a efetiva reparação sobreviria.

Palavras-chave: Organizações internacionais, Responsabilidade internacional, Privilégios e imunidades, Tribunais internos, Ultra vires

\begin{abstract}
This article intends to discuss new possibilities for the accountability of international organizations, disregarding the privileges and immunities normally assigned to them, which prevent the adoption of equitable remedies for those who suffered losses for their actions and omissions when performing their activities as prescribed in their constitutive acts. Therefore, at first, this paper aims (1) at explaining why international organizations can act at the international level and (2) pointing out the types of benefits that such bodies bear under international law. Subsequently, this work intends to (3) describe the international responsibility of organizations, presenting the requirements needed to assign an offense to an entity, as well as (4) outline the possibilities to disregard their immunities for the violation of a rule rule of international law. At the end, it is concluded that in the absence of a mechanism for a dispute to take place within the setting of an organization and in case such entity exceeds the limits of its functions, immunity could be waived and proper remedies would be upheld.
\end{abstract}

Keywords: International organizations, International responsibility, Privileges and immunities, Internal courts, Ultra vires

\footnotetext{
${ }^{1}$ Doutoranda em Direito pela Universidade Federal do Rio Grande do Sul - UFRGS, Rio Grande do Sul, RS. (Brasil).Professora do Centro Universitário Ritter dos Reis - UniRITTER, Rio Grande do Sul. (Brasil). E-mail: tatiafrcardoso@ gmail.com.
} 


\section{INTRODUÇÃO}

Os sujeitos tradicionais da ordem internacional são os Estados, vez que é a partir das suas interações, propiciando a criação dos direitos e obrigações internacionais, que o próprio Direito Internacional se desenvolvera até meados do século XX. Entretanto, hodiernamente, há outros atores recorrentemente atuando na órbita internacional, os quais, aliados ao desenvolvimento das relações interacionais, fomentam a ampliação e a diversificação dos sujeitos desse ramo do Direito.

E no momento em que as organizações internacionais passam a possuir direitos e assumir deveres no plano externo, elas se tornam exemplos dessa nova realidade, não sendo mais possível afirmar que os Estados são os únicos entes capazes de operar no Direito Internacional. Com isso, impossível negar a possibilidade desses entes em cometerem atos ilícitos e causarem prejuízos, já que, ao levarem a cabo suas condutas, podem acabar indo de encontro às normas internacionalmente reconhecidas e igualmente a si atribuídas.

Contudo, no âmbito internacional, as organizações internacionais possuem privilégios e imunidades, cuja função é possibilitar que às mesmas desempenhem os seus objetivos sem sofrer reprimendas por parte dos Estados, garantindo-lhes segurança na condução das suas operações. Assim, mesmo na ocorrência de um ilícito, muitas vezes não é possível haver uma justa reparação, posto que no pólo passivo encontra-se uma organização a qual, por sua vez, possui imunidade frente às cortes nacionais. Consequentemente, a única hipótese de reparação ocorreria em âmbito internacional - instância essa que igualmente encontra limites quanto a ter uma organização como parte em uma demanda.

Em razão disso, o presente tema torna-se relevante para que possíveis contornos a essas imunidades sejam verificados, de modo que haja a devida responsabilização dessas entidades quando, ao agirem ou omitirem-se na realização de suas finalidades, causarem um prejuízo à outrem. Para tanto, o texto parte da explanação das organizações internacionais enquanto sujeitos plenamente capazes em direito internacional, expondo as suas características basilares, incluindo os privilégios e imunidades que elas ostentam em direito internacional. Na sequência, dirige-se a análise da atribuição de certo ato ilícito à uma determinada organização, bem como ao estudo de duas possibilidades atinentes à viabilidade de cortes domésticas ouvirem casos contra essas entidades pela violação de uma regra de direito internacional, afastando-se a sua imunidade. 
Para o desenvolvimento desse escrito, realizou-se uma revisão da bibliografia e da jurisprudência existente sobre organizações internacionais e suas imunidades, sem o condão de querer esgotá-las, a fim de que fossem encontrados argumentos possíveis para garantir-se uma efetiva reparação aos prejuízos causados por essas entidades, responsabilizando-as por atos ilícitos por si praticados direta ou indiretamente ao desempenharem suas atividades.

\section{AS ORGANIZAÇÕES INTERNACIONAIS ENQUANTO SUJEITOS DE DIREITO INTERNACIONAL.}

Até o limiar do século $\mathrm{XX}$, as relações entre os Estados ocorriam de forma predominantemente bilateral, na busca por um parceiro em uma determinada área, como a comercial ou a bélica, por exemplo. Por vezes, essas parcerias ocorriam de forma contínua, todavia, nunca fugindo da perspectiva estritamente bilateral e de existência mútua, ou seja, de coexistência de dois Estados distintos, os quais, por vezes, uniam suas forças. ${ }^{1}$

Todavia, desde a revolução industrial já brotava a perspectiva de transfronteiriçidade, isto é, da crescente (porém incipiente) necessidade de compartilhar internacionalmente ideais mínimos. ${ }^{2}$ Nesse sentido, com o alargamento dos problemas mundiais, seja daqueles oriundos da guerra, como os refugiados e os prejuízos humanitários, seja aqueles oriundos do aperfeiçoamento econômico, como os incidentes trabalhistas ou ambientais de cunho mundial (poluição marítima, buraco na camada de ozônio, etc.), a incapacidade do Estado em unilateralmente ou, até mesmo, bilateralmente resolvê-los faz com que houvesse a necessidade da sua união com os demais.

Afinal, para que as ações possam surtir efeitos ao redor do globo, faz-se imperioso que os Estados se unam em prol de objetivos comuns, agindo cooperada e coordenadamente nos mais diversos assuntos, para além de meras conferências e da assinatura de tratados que estipulem novas regras cuja efetividade é improvável em um cenário maquiavélico. Assim, diante dessa necessidade de institucionalização da política e do diálogo internacional, é que emergem as organizações internacionais.

Nesse sentido, poder-se-ia qualificar as organizações internacionais como organismos interestatais constituídos por ações voluntárias dos Estados, criados para conduzir e fomentar intergovernamentais, têm como objetivo central estabelecer canais efetivos de diálogo e de 
cooperação internacional coordenada entre eles em matérias de interesse comum. ${ }^{3}$ Em outras palavras, essas coletividades, igualmente conhecidas como entidades ação entre os Estados sobre os mais diversos temas, possibilitando efetivamente uma colaboração entre eles em prol de interesses coletivos.

Logo, como bem aponta Marie-Claude Smouts acerca do nascimento das organizações internacionais, a vida internacional não estaria mais atrelada a "apenas regulamentar relações internacionais essencialmente horizontais e bilaterais, mas de favorecer a ação coletiva para a realização de objetivos comuns". ${ }^{4}$ Por isso, com a mundialização de situações, a concretização da multilateralidade das relações internacionais através de organismos independentes do Estado que opere em prol de objetivos comuns se torna importante.

E justamente por estar apartada da figura estatal, mas com papel tão importante de unir esforços para combater os incidentes eminentemente internacionais, é que surgem direitos e deveres direcionados especificamente a essas coletividades interestatais - ou seja, nasce outro sujeito de direito internacional, com capacidade autônoma de ação no ambiente externo. Quer isto dizer que as organizações internacionais possuem personalidade jurídica própria, podendo agir no plano internacional de forma independente de seus membros por serem detentoras de direitos e deveres específicos ${ }^{5}$, bem como por exercer direitos de legação ${ }^{6}$, estabelecendo as suas próprias relações com os demais entes internacionais.

\footnotetext{
${ }^{1}$ SMOUTS, Marie-Claude. A cooperação internacional: da coexistência à governança mundial. In: SMOUTS, Marie-Claude (org.). As Novas Relações Internacionais: práticas e teorias. Brasília: Ed. Universidade de Brasília, 2004, p. 131.

${ }^{2}$ HERZ, Monica; HOFFMAN, Andrea Ribeiro. Organizações Internacionais: história e práticas. Rio de Janeiro: Elsevier, 2004, p. 32.

${ }^{3}$ SEITENFUS, Ricardo. Manual das Organizações Internacionais. Porto Alegre: Livraria do Advogado, 2000, p. 26; VELASCO, Manuel Diez. Las Organizaciones Internacionales. Madrid: Tecnos, 1999, p. 49.

${ }^{4}$ SMOUTS, op cit., p. 133.

${ }^{5}$ CANÇADO TRINDADE, Antônio Augusto. Direito das Organizações Internacionais. Belo Horizonte: Del Rey, 2002, p. 12.

${ }^{6}$ MELLO, Celso D. de Albuquerque. Curso de Direito Internacional Público. Vol. I. $4{ }^{\text {a }}$ ed. Rio de Janeiro: Freitas Bastos, 1974, p. 317.
} 
Acerca disso, Paulo Henrique G. Portela defende a personalidade jurídica internacional apartada das organizações por serem elas "responsáveis pelos atos que praticam e pelas obrigações que deve[ria]m cumprir". ${ }^{7}$ Além disso, estende-se tecendo que elas têm “capacidade de auto-organização, podendo estabelecer seus próprios órgão e métodos de trabalho" e, por isso, devem ser vistas como uma figura independente à dos Estados que as compõe. ${ }^{8}$

Mister notar que a personalidade jurídica das organizações normalmente lhe é atribuída por seus membros por intermédio de tratado, tal como ocorrera com o MERCOSUL, através do Protocolo de Ouro Preto 9 . Todavia, mesmo quando não expressa, já é do entendimento da comunidade internacional que elas detêm personalidade jurídica no momento em que passam a executar atos tipicamente internacionais para atingir os seus fins ${ }^{10}$, forte nos pareceres consultivos emitidos pela Corte Permanente de Justiça Internacional em 1927 acerca da personalidade jurídica da Comissão Europeia do Danúbio ${ }^{11}$ e pela Corte Internacional de Justiça em 1949 acerca da personalidade jurídica das Nações Unidas (ONU) ${ }^{12}$.

${ }^{7}$ PORTELA, Paulo Henrique G. Direito Internacional Público e Privado. 4a ed. Salvador: Juspodivm, 2012, p. 257.

${ }^{8}$ Ibid, p. $257-258$.

9 Art. 34: “o Mercosul terá personalidade jurídica de Direito Internacional”. MERCOSUL. Protocolo de Ouro Preto. 1994 [no Brasil, Dec. 1.901/96]. Outro exemplo é a Convenção de Montego Bay quanto a personalidade da Autoridade Jurídica Internacional de Fundos Marinhos. ONU. Convenção da ONU sobre o Direito do Mar. 1982 [no Brasil Dec. 99.165/90], art. 176.

${ }^{10}$ Um exemplo dessa situação era a União Europeia, tal como explica Benjamin: “[o] Tratado de Maastricht, por exemplo, não contém disposições expressas sobre a personalidade jurídica da EU, conferida só recentemente pelo Tratado de Lisboa". Frisa-se que esse está no art. 47 do referido documento. BENJAMIN, Daniela Arruda. A Aplicação dos Atos de Organizações Internacionais no Ordenamento Jurídico Brasileiro. Brasília: FUNAG, 2014, p. 27; UNIÃO EUROPEIA. Tratado de Lisboa. 2007.

11 Essa opinião confirmou a total independência dos poderes atribuídos a essa comissão em relação aos seus membros (França, Grã-Bretanha, Itália e Romênia), confirmando implicitamente a sua personalidade jurídica. PCIJ. Jurisdiction of the European Commission of the Danube. Advisory Opinion publicada em $08 \mathrm{dez}$. 1927 , p. 43 e 63-64.

${ }^{12}$ Especificamente, esse caso reconhecera de modo explícito a capacidade da ONU para reivindicar o seu direito de satisfação/reparação em virtude da morte, em 1948, de Folke Bernadotte, mediador para o Oriente Médio. Nas linhas de Mello, a Corte de Haia "em um parecer que declarava que, em um sistema jurídico, todos os sujeitos não precisavam ter os mesmos direitos e deveres; assinalava que a ONU já havia concluído tratados internacionais e finalmente salientava que ela só poderia realizar os seus fins se tivesse personalidade internacional". MELLO (1974), op cit., p. 315; ICJ. Reparation for Injuries Suffered in the Service of the United Nations. Advisory Opinion publicada em 11 abr. 1949. 
As organizações internacionais, diferentemente dos Estados cujas características essenciais são elencadas em tratado internacional, não possuem uma convenção-chave onde estão listados seus elementos constitutivos. Todavia, seus atributos fundamentais estão na própria definição das Organizações. Por conseguinte, interessante ressaltar a acepção elucubrada por Ângelo Piero Sereni, onde se visualiza quatro elementos principais:

\begin{abstract}
A organização internacional é uma (a) associação voluntária de sujeitos de direito internacional, constituída por (b) ato internacional e disciplinada nas relações entre as partes por normas de direito internacional, que se realiza em um ente de aspecto estável, que possui um ordenamento jurídico interno próprio e é dotado de (c) órgão $e$ institutos próprios, por meio dos quais realiza as finalidades comuns dos seus membros mediante (d) funções particulares e o exercício dos poderes que lhe foram conferidos. ${ }^{13}$ (grifos nossos)
\end{abstract}

Nesse interim, destaca-se que as organizações são sujeitos secundários de Direito Internacional, já que formadas pelo aceite voluntário e expresso de $\operatorname{Estados}^{14}$, a partir da comunhão de anseios e ambições. ${ }^{15}$ Para tanto, formalizam essas convicções em um documento vinculante que estipula não só os objetivos ${ }^{16}$ como também as regras internas e as estruturas permanentes do organismo ${ }^{17}$, tal como a 'constituição' para os Estados ${ }^{18}$.

Por fim, a realização de funções particulares por uma organização internacional enquanto elemento constitutivo essencial para a sua existência, está atrelada ao exercício de seus poderes de forma plena e independente perante a comunidade internacional, mesmo que delimitados pelos Estados no momento da sua edificação ${ }^{19}$. Trata-se, consequentemente, do exercício da vontade das organizações internacionais, por meio de suas resoluções e recomendações ${ }^{20}$, de forma apartada de seus membros, porém, direcionados à eles, em busca de uma gestão ideal dos interesses balanceados destes.

\footnotetext{
${ }^{13}$ SERENI, Ângelo Piero apud MELLO (1974), op cit., p. 314.

${ }^{14}$ Insta mencionar que existem organizações internacionais que não são formadas apenas por Estados, em que pese ser essa a formação mais comum. Nesse sentido, cita Benjamin a Organização Internacional do Trabalho (OIT), cuja composição é tripartite, formada por representantes de entidades de trabalhadores, empregadores e governo; ou, ainda, a Organização para Alimentação e Agricultura (FAO) e a Organização Mundial do Comércio (OMC) que aceitam outros organismos como membros, como a União Europeia. Ademais, note-se que essa possibilidade advém da própria personalidade jurídica concedida às Organizações. BENJAMIN, op cit.,p. 26-27.

${ }^{15}$ SEITENFUS, op cit., p. 35.

${ }^{16}$ A respeito desse tema, importante lembrar a interpretação da Corte Internacional de Justiça, para quem as organizações "são governadas pelo princípio da especialidade, isto é, são investidas de poderes pelos Estados
} 
E essa característica de independência, buscando suas finalidades próprias através de poderes outorgados por seus membros, lhe permite também negociar em seu próprio nome, contraindo empréstimos e assumindo obrigações. Noutros termos, ser detentora de funções particulares igualmente se refere a sua vontade jurídica exclusiva, uma vez que dotada de personalidade jurídica internacional autônoma. ${ }^{21}$

Sem sobra de dúvidas, a atuação das organizações internacionais têm impactado as relações internacionais hodiernas, mantendo-as mais diversificadas, equilibradas e ordenadas. $^{22}$ Ao longo dos anos, foram criadas diversas organizações internacionais - no século XX, conforme Daniela Arruda Benjamin, especificamente “entre 1965 e 1989, em média, foram criadas 26 organizações internacionais a cada cinco anos. Na década de 90, esse número cresceu para 30, caindo, não obstante, para 14 nos anos $2000{ }^{23}$

ue as criam, limitando as suas funções àquelas estipuladas por eles conforme seus interesses comuns". ICJ. Legality of the Use by a State of Nuclear Weapons in Armed Conflict. Advisory Opinion publicada em 08 jul. 1996, pp. 24.

${ }^{17}$ PORTELA, op cit., p. 255.

${ }^{18}$ Acerca disso, ressalta Cançado Trindade que os tratados constitutivos de organizações internacionais vão além de meros tratados multilaterais (logo, podendo ser chamados de constituições) por criarem um organismo com personalidade jurídica apartada da dos membros, fazendo com que se diferenciem de outros documentos que normalmente criam obrigações às partes contratantes. Contudo, ressalta o autor que a Carta da ONU não seria um exemplo dessa interpretação, haja vista ela produzir efeitos não apenas inter partes (como nos artigos 2[6], 35[2], 90 e 93[2] ), indo além de sua natureza jurídica original para realizar determinadas ações. CANÇADO TRINDADE, op cit., p. 27-28.

${ }^{19}$ HERZ; HOFFMAN, op cit., p. 22.

20 Há normalmente dois tipos de atos em organizações internacionais: os vinculantes (hard law) e os recomendatórios (soft law), em que os primeiros geram obrigações para as partes e os últimos criam diretrizes para os membros. A nomenclatura, todavia, varia de organização para organização. Na OIT, por exemplo, as resoluções/convenções são vinculantes, já as recomendações são diretrizes, ao passo que na ONU depende-se do órgão que as exaram - as resoluções da Assembleia Geral, por exemplo, serão diretrizes, enquanto as do Conselho de Segurança, tomadas com base no capítulo VII da Carta da ONU, serão mandatórias. CANÇADO TRINDADE, op cit., p. 41-42; O'CONNELL, Mary Ellen. The Role of Soft Law in a Global Order. In: SHELTON, Dinah (Ed.). Commitment and Compliance: The Role of Non-Binding Norms in the International Legal System. New York: Oxford University Press, 2003, p. 100-114.

${ }^{21}$ Nesse interim, salienta-se o apontamento feito por Benjamin, para quem os poderes atribuídos às organizações internacionais não excluem a competência dos Estados-membros para tais, sendo a transferência apenas uma forma de exercer esses atos "através de um ente comum" - longe de uma abdicação completa. Logo, os "Estados preservam competência para atuar", porém, o fazem "nos domínios específicos da OI”. BENJAMIN, op cit.,p. 31.

${ }^{22}$ SEITENFUS, op cit., p. 25-27; CANÇADO TRINDADE, op cit., p. x; HERZ; HOFFMAN, op cit., p. 23; BENJAMIN, op cit.,p. 33; BULL, Hedlet. A Sociedade Anárquica: um estudo da ordem na política mundial. Brasília: Editora UnB, 2002, p. 89.

.$^{23}$ BENJAMIN, op cit.,p. 23. 
Organizações essas que podem classificadas quanto a sua finalidade ${ }^{24}$ (política, militar, econômica, social, etc.), o seu alcance territorial ${ }^{25}$ (universal ou regional), a natureza dos seus poderes ${ }^{26}$ (intergovernamentais ou supranacionais), dentre outras rotulações ${ }^{27}$, as quais, cada qual dentro de seu ramo de expertise, assumem cada vez mais obrigações importantes no plano internacional. Em vista disso, devem elas ser amparadas por um conjunto de medidas específicas a fim de que atinjam os seus objetivos. E um desses instrumentos são os privilégios e imunidades, sem os quais, talvez, as organizações não conseguissem realizar todas as ações necessárias para alcançar os fins programados em seus atos constitutivos. $^{28}$

Nesse viés, considerando os privilégios e imunidades um ponto central para a execução das ações das organizações internacionais, o texto seguirá com o estudo desses institutos, em especial, ressaltando as prerrogativas da ONU, haja vista essa organização ter o condão de zelar pela paz e segurança internacionais - fundamentos essenciais da ordem internacional pós- $45^{29}$.

\footnotetext{
${ }^{24}$ Esta classificação está relacionada aos fins da própria organização, ou seja, depende do objetivo que é buscado para erguer tal organismo, os quais podem ser gerais ou específicos. No que tange o primeiro, exemplifica-se pela ONU e OEA, com fins políticos. Já aquelas com domínios especiais, há a OTAN, com fins militares, o FMI (Fundo Monetário Internacional), com fins econômicos, a OIT e a OMS (Organização Mundial da Saúde), com fins sociais, etc.

${ }^{25}$ Esta classificação está relacionada à abrangência da própria organização, normalmente, dividida entre regional e universal. São exemplos o MERCOSUL e a ONU, respectivamente.

${ }^{26}$ Esta classificação está relacionada à estrutura da organização. As organizações intergovernamentais podem ser exemplificadas pela OEA, pois buscam a cooperação coordenada dos membros para um determinado fim comum, sendo que os seus próprios representantes integram os órgãos da organização, votam diretamente para a adoção de uma medida e internalizam as resoluções do organismo. Com relação às supranacionais, o exemplo clássico é a União Europeia. Nesse tipo de organização, os órgãos internos são formados por representantes autônomos, ou seja, por titulares independentes, os quais não votam nos interesses dos seus Estados, sendo aprovadas de forma majoritária. Ademais, as decisões e resolução são auto-executáveis no plano doméstico dos Estados, não dependendo das ações destes para serem implementadas. CARNEIRO, Cynthia S. O Direito da Integração Regional. Belo Horizonte: Del Rey, 2007, p. 30-41.
}

27 Para mais classificações, cf. SEITENFUS, op cit., p. 44-52; CAMPOS, João Mota de. Organizações Internacionais: teoria geral. $3^{a}$ ed. Curitiba: Juruá, 2010, p. 49-58; VELASCO, op cit., p. 48-53.

${ }^{28}$ MELLO (1974), op cit., p. 321; SHAW, Malcolm N. International Law. $5^{\text {a }}$ ed. Cambridge: Cambridge University Press, 2003, p. 1205-1206.

${ }^{29}$ Nesse escopo, cumpre destacar o entendimento de Rezek ao anotar que os Estados, mesmo antes da Segunda Guerra Mundial, já assumiam a paz e a segurança como fundamentais para o futuro da sociedade internacional. Entretanto, para o autor, com o desenvolvimento das organizações internacionais, em especial da ONU, nota-se que essas ambições são muito mais amplas, posto que não é apenas a desordem/guerra que é rechaçada, buscando-se igualmente a harmonia entre os povos e a estabilidade das relações internacionais - o que é desenvolvido por essa Organização a partir da sua edificação em 1945. REZEK, José Francisco. Direito Internacional Público: curso elementar. $9^{a}$ ed. São Paulo: Saraiva, 2002, p. 239-240. 


\section{OS PRIVILÉGIOS E IMUNIDADES DAS ORGANIZAÇÕES INTERNACIONAIS}

Os privilégios e imunidades garantidos às organizações internacionais podem ser entendidos como "padrões mínimos de liberdade e de segurança jurídica conferidos às posses, à sede e outros escritórios, bem como aos funcionários e demais servidores acreditados" desses entes, para que eles possam levar a cabo os seus objetivos da forma mais eficiente e imparcial possível sem que sofram quaisquer restrições pelos Estados. ${ }^{30}$ Noutros termos, os privilégios e imunidades são benefícios garantidos às organizações que afastam os direitos jurisdicionais inerentes aos Estados, de modo que esses se abstenham do tradicional exercício de suas competências básicas, permitindo que os organismos ali presentes conduzam de forma apropriada as suas atividades aos fins previamente instituídos.

Sands e Klein explicam que o "apropriado" seria tudo "aquilo que é necessário para a organização levar a cabo suas funções de maneira imparcial, eficiente e econômica". ${ }^{31}$ Além da própria Corte Internacional de Justiça, que se posicionou em 1989 no sentido de que os privilégios e imunidades conferidos às organizações são importantes para o exercício independente das funções nos Estados-membros onde atuam ${ }^{32}$, diversos precedentes corroboram com essa visão:

Em Mendaro v. Banco Mundial [1983], a Corte de Apelações norte-americana do Distrito Central estipulou que a razão para garantir imunidades às organizações internacionais é permitir que elas persigam as suas funções de forma mais eficiente e, particularmente, que lhes seja permitido operar livremente, sem serem controladas pelo Estado-membro onde as atividades estejam sendo realizadas. No Tribunal Arbitral EUA-Irã v. AS [1985], a Corte Suprema holandesa confirmou a necessidade de conferir garantias às organizações internacionais para que elas possam realizar suas tarefas de forma independente e livres de interferência em quaisquer circunstancias; e notou que elas não são, em principio, sujeitas a jurisdição dos Estados-membros em relação a casos concernentes as suas atividades. A Corte de Cassação italiana, em FAO v. INPDAI [1982], determinou que as atividades que afetam diretamente os propósitos institucionais da organização terão imunidade, do mesmo modo que anotou o Tribunal de Apelação do Trabalho [inglês], em Mukuro v. Banco Europeu para a Reconstrução e Desenvolvimento [1994], que a imunidade de julgamento é justificada com base na necessidade de atingir os propósitos do banco em questão de forma independente, ininterrupta e neutra, sem ser controlada ou sofrer interferência do Estado-receptor. ${ }^{33}$

\footnotetext{
${ }^{30}$ CRAWFORD, James. Brownlie's Principles of Public International Law. $8^{\text {a }}$ ed. Oxford: Oxford University Press, 2012, p. 171.

${ }^{31}$ SANDS, Philippe; KLEIN, Pierre. Bowett's Law of International Institutions. $6^{\text {a }}$ ed. London: Street \& Maxwell, 2009, p. 515-516.

${ }^{32}$ ICJ. Applicability of Article VI, Section 22, of the Convention on the Privileges and Immunities of the United Nations. Advisory Opinion publicada em 15 dez. 1989, pp. 195-196.

${ }^{33}$ SHAW, op cit., p. 1208.
} 
Logo, pode-se dizer que os privilégios e imunidades conferidos às organizações perante seus Estados-membros têm se cristalizado em uma regra costumeira de direito internacional. ${ }^{34}$ No entanto, não se pode afirmar que essa normativa seria a mesma confiada aos Estados em razão do costume assentado no preceito par in parem non habet imperium vel judicium. ${ }^{35}$ Em que pese serem análogas quanto ao conteúdo, as facilidades conferidas se distinguem porque no âmbito dos Estados são os princípios da igualdade soberana e da reciprocidade que garantem o respeito para com os privilégios e imunidades atribuídos ao ente pelo Estado acreditado, enquanto que no âmbito das organizações elas decorrem de tratados. ${ }^{36}$

Afinal, os privilégios e imunidades das organizações advêm inicialmente de convenções internacionais, particularmente, de seus tratados constitutivos, onde serão encontrados, no mínimo, previsões gerais sobre o tema. ${ }^{37}$ A Carta da ONU é um exemplo desses instrumentos, encontrando-se no artigo 105 a seguinte prescrição:

1. A Organização gozará no território de cada um de seus Membros dos privilégios e imunidades necessários à realização de seus propósitos. 2. Os representantes dos Membros das Nações Unidas e os funcionários da Organização gozarão, igualmente, dos privilégios e imunidades necessários ao exercício independente de suas funções relacionadas com a Organização. 3. A Assembleia Geral poderá fazer recomendações com o fim de determinar os pormenores da aplicação dos parágrafos 1 e 2 deste Artigo ou poderá propor aos Membros das Nações Unidas convenções nesse sentido. ${ }^{38}$

\footnotetext{
${ }^{34}$ SOARES, Guido Fernando. Das Imunidades de Jurisdição e de Execução. Rio de Janeiro: Forense, 1984, p. 164. Alguns precedentes também são explícitos nesse sentido: em Eckhardt v. Eurocontrol - no. 2 [1984], a Corte Distrital de Maastricht assentou que as organizações internacionais possuem imunidade de jurisdição com base no direito costumeiro; bem como a Corte de Trabalho Suíça, a qual, no caso ZM v. Delegação Permanente da Liga Árabe para a ONU [1993], reconheceu que o direito internacional costumeiro é que reconheceu que as organizações internacionais, regionais ou universais, possuem imunidade de jurisdição. SHAW, op cit., p. 1207-
} 1208.

${ }^{35}$ VARELLA, Marcelo Dias. Direito Internacional Público. $3^{\text {a }}$ ed. São Paulo: Saraiva, 2011, p. 340.

${ }^{36}$ CRAWFORD, op cit., p. 171; SHAW, op cit., p. 1205; A Corte de Cassação belga julgou o caso League of Arab States v TM [2001] nesse mesmo sentido.

${ }^{37}$ CRAWFORD, op cit., p. 172; SOARES, op cit., p.168.

${ }^{38}$ ONU. Carta das Nações Unidas. 1945 [no Brasil, Dec. 19.841/45]. No mesmo sentido, por exemplo, v. arts. 133 a 135 da Carta da OEA (OEA. Carta da Organização dos Estados Americanos. 1948. [no Brasil, Dec.30.544/52]); e art. 22 do Tratado da UNASUL (UNASUL. Tratado Constitutivo da União de Nações SulAmericanas. 2008 [no Brasil, Dec. 7.667/12]).

${ }^{39}$ Especificamente quanto às imunidades fiscais previstas no tratado, cumpre salientar a existência de extensa jurisprudência no Brasil, cujo precedente é o REsp 1.159.379/DF (STJ. Recurso Especial n. 1.159.379/DF. 
Ao mesmo tempo em que as organizações arquitetam previsões gerais em seus documentos basilares, elas também criam tratados específicos quanto aos privilégios e imunidades, como realizado pela ONU em 1946. Trata-se da Convenção sobre Privilégios e Imunidades das Nações Unidas, oriunda da Assembleia Geral, onde estão previstas imunidades e inviolabilidades relativas às propriedades, fundos, arquivos e haveres (art. 2), ao respeito pela comunicação (art. 3), os benefícios e imunidades de seus funcionários e de seus vencimentos e bens (arts. 5 e 6$)^{39}$ e a possiblidade do organismo em emitir laissez-passer (art. 7). ${ }^{40}$

E especificamente quanto à sede, cumpre salientar a existência do Headquarters Agreement firmado entre Estados Unidos e a ONU em 1947, o qual especifica, por exemplo, a inviolabilidade do prédio em Nova York e a não aplicação do instituto da persona non grata por esse país a indivíduos ligados à organização ${ }^{41}$ - matérias igualmente conectadas aos benefícios em apreço. ${ }^{42}$

Além disso, quando se trata de um representante estatal, este terá imunidade plena no Estado acreditado e sempre poderá ser julgado pelo Estado acreditante ${ }^{43}$ - o que nem sempre ocorre no caso das organizações. Isso porque, no caso do funcionário internacional, "os privilégios e imunidades podem ser invocados inclusive perante o Estado de nacionalidade ou residência [do indivíduo]", cabendo à organização tomar as medidas adequadas para a solução de controvérsias. ${ }^{44}$

Registro n. 2009/0194481-9. Relator Min. Teori Albino Zavascki, Julgado em 08 jun. 2011 - 1a seção, Publicado no DJe em 27 jun. 2011).

${ }^{40}$ ONU. Convenção sobre Privilégios e Imunidades das Nações Unidas. 1946 [no Brasil, Dec. 27.784/50]. Similarmente, pode-se citar o art. 7, seções 1 a 10 do Acordo do Banco Internacional para a Reconstrução e Desenvolvimento. BANCO MUNDIAL. IBRD Articles of Agreement. 1944.

${ }^{41}$ ONU. Agreement between the UN and the USA regarding the Headquarters of the UN. 1947. Para comentários sobre o tratado cf.: ASIL. Notes on Legal Questions concerning the United Nations. The American Journal of International Law. Washington D.C., v. 42, n. 2, pp. 445-447, abr. 1948.

${ }^{42}$ Semelhante é o caso do acordo de sede firmado entre Uruguai e o MERCOSUL, nos arts. 4 a 6 e 9 a 12. MERCOSUL. Decisão do Conselho Mercado Comum n. 4. 1996.

${ }^{43}$ Cf. ONU. Convenção de Viena sobre Relações Diplomáticas. 1961 [no Brasil, Dec. 56.435/65]; REZEK, op cit., p. 201-204.

${ }^{44}$ ICJ (1989), op cit., p. 196. No mesmo sentido cf. SHAW, op cit., p. 1210. De maneira diversa, porém, entende o Ministério das Relações Exteriores brasileiro, o qual, segundo Lima, não concede benefícios a funcionários internacionais brasileiros (LIMA, Sergio Eduardo M. Imunidade Diplomática: instrumento de Política Externa. Rio de Janeiro: Lumen Juris, 2004, p. 126-127). 
Todavia, quando um funcionário atuar de forma puramente privada - o que será averiguado pela própria organização ${ }^{45}$ - "é a regra que ele estará sujeito à jurisdição nacional de seu Estado de residência", vez que os benefícios relativos a esses indivíduos restringem-se aos atos funcionais ${ }^{46}$, excepcionadas raras situações ${ }^{47}$.

Sobre o tema, o argumento trazido por Bekker merece destaque, ao tecer que todas as atividades das organizações internacionais, sejam elas jure imperii ou jure gestionis, deveriam sempre estar relacionadas aos seus objetivos funcionais, tal como assentado nos seus textos constitutivos, de modo que não há como discutir uma potencial equiparação a um ente privado para fins de revogar a imunidade da entidade sem que isso atinja a sua própria atividade-fim outrora apontada e aceita por seus respectivos membros. ${ }^{50}$

\footnotetext{
${ }^{45}$ ICJ. Difference relating to immunity from legal process of a Special Rapporteur of the Commission on Human Rights. Advisory Opinion publicada em 29 abr. 1999, pp. 67; CRAWFORD, op cit., p. 178.

${ }^{46}$ SHMALENBACH, Kirsten. Third Party Liability of International Organizations. In: LANGHOLTZ, Harvey; KONDOCH, Boris; WELLS, Alan. International Peacekeeping: the yearbook of international peace operations. Vol. 10. Hague: Martinus Nijhoff Pub., 2006, p. 40. Aliás, importante ressaltar a existência da Vienna Convention on the Representation of States in their Relations with International Organizations, de 1975, sobre os representantes estatais perante organizações (e não funcionários internacionais), espelhando-se na Convenção de Viena de 1961 sobre Relações Diplomáticas, mas que ainda não está em vigor. Isso, pois, o entendimento da comunidade internacional tem sido no sentido de também atribuir imunidade limitada aos atos oficiais ou em razão destes à representantes estatais, tal como exteriorizado em documentos específicos de cada organização. CRAWFORD, op cit., p. 179; CAMPOS, op cit., p. 153.

${ }_{47}$ São os casos, por exemplo, dos juízes da Corte Internacional de Justiça; do Secretário-Geral e todos os subsecretários-gerais; e do diretor-executivo das agências especializadas da ONU, inclusive qualquer funcionário que responda por ele durante sua ausência das funções, os quais terão os privilégios e imunidades, isenções e facilidades idênticos aos dos enviados diplomáticos. ONU. Convenção sobre Privilégios e Imunidades das Nações Unidas. 1946, art. 5, seção 19; ONU. Convenção sobre Privilégios e Imunidades das Agências Especializadas das Nações Unidas. 1947 [no Brasil, Dec. 52.288/63], art. 6, seção 21; ONU. Estatuto da Corte Internacional de Justiça. 1945, Art. 19.

${ }^{48}$ Nos dizeres de Di Pietro, "atos de império seriam os praticados pela Administração [Pública] com todas as prerrogativas e privilégios de autoridade unilateral e coercitivamente ao particular independentemente de autorização judicial, sendo regidos por um direito especial exorbitante do direito comum, porque os particulares não podem praticar atos semelhantes, a não ser por delegação do poder público. Atos de gestão são os praticados pela Administração [Pública] em situação de igualdade com os particulares, para a conservação e desenvolvimento do patrimônio público e para a gestão de seus serviços; como não diferem a posição da Administração e a do particular, aplica-se a ambos o direito comum". DI PIETRO, Maria Sylvia Z. Direito Administrativo. $15^{\text {a }}$ ed. São Paulo: Atlas, 2003, p. 212-213.

${ }^{49}$ SHAW, op cit.,p. 1205-1206; HIGGINS, Rosalyn. Problems and Process: international law and how we use it. New York: Oxford University Press, 1994, p. 91-93; FOX, Hazel; WEBB, Philippa. The Law of State Immunity. $3^{\mathrm{a}}$ ed. Oxford: Oxford University Press, 2013, p. 574-575 (citando os seguintes casos: Sassetti v. Força Multinacional de Paz e Observadores [julgado na Itália, em 1994, discutindo a terminação de contrato de emprego em que a imunidade foi garantida com base no Tratado de Sede firmado em 1982]; Ruperas v. Organização Europeia de Telecomunicações via Satélite [julgado pela Corte da Cassação francesa em 2001, debatendo questões trabalhistas, as quais foram afastadas com base no Acordo de Sede firmado em 1982]; SCIMET v. Banco Africano de Desenvolvimento [julgado pela Corte de Primeira Instância de Bruxelas, em 1997, onde uma empresa belga buscava levantar a imunidade do banco por não ter recebido pela prestação de serviço em um projeto de purificação de água no Chad apoiado por ele, não tendo sucesso com base no Tratado Constitutivo da entidade]).

${ }^{50}$ BEKKER, Peter H. The Legal Position of Intergovernmental Organizations. Hague: Martinus Nijhoff Pub., 1994, p. 165. No mesmo sentido, cf.: US COURT OF APPEALS - D.C. Broadbent v. Organization of American States. 1980 (casua trabalhista em que a imunidade não foi retirada, pois não foi possível considerar o emprego de funcionário internacional um 'ato de gestão' haja vista os fins da organização).
} 
Inclusive, acerca disso, importante ressaltar o posicionamento brasileiro, cujo entendimento alinha-se ao do plano externo no sentido de que as imunidades de jurisdição são absolutas no caso das organizações, quer se tratando de atos normalmente tidos como privados ou aqueles eminentemente classificados como públicos, apartando-se do viés relativizado já devidamente assentado no ordenamento pátrio quanto aos atos dos Estados ${ }^{51}$ :

DIREITO INTERNACIONAL PÚBLICO. DIREITO CONSTITUCIONAL. IMUNIDADE DE JURISDIÇÃO. ORGANIZAÇÃO DAS NAÇÕES UNIDAS (ONU). PROGRAMA DAS NAÇÕES UNIDAS PARA O DESENVOLVIMENTO

(ONU/PNUD). RECLAMAÇÃO TRABALHISTA. CONVENÇÃO SOBRE PRIVILÉGIOS E IMUNIDADES DAS NAÇÕES UNIDAS (DECRETO 27.784/1950). APLICAÇÃO. 1. Segundo estabelece a "Convenção sobre Privilégios e Imunidades das Nações Unidas”, promulgada no Brasil pelo Decreto 27.784, de 16 de fevereiro de 1950, "A Organização das Nações Unidas, seus bens e haveres, qualquer que seja seu detentor, gozarão de imunidade de jurisdição, salvo na medida em que a Organização a ela tiver renunciado em determinado caso. Fica, todavia, entendido que a renúncia não pode compreender medidas executivas. 2. Esse preceito normativo, que no direito interno tem natureza equivalente a das leis ordinárias, aplica-se também às demandas de natureza trabalhista. 3. Recurso extraordinário provido. ${ }^{52}$ (grifos nossos)

RECURSO DE REVISTA DO $1^{\circ}$ RECLAMADO. PROGRAMA DAS NAÇÕES UNIDAS PARA O DESENVOLVIMENTO - PNUD. IMUNIDADE DE JURISDIÇÃO. Esta Corte editou a Orientação Jurisprudencial 416 da SBDI-1 do TST, segundo a qual "as organizações ou organismos internacionais gozam de imunidade absoluta de jurisdição quando amparados por norma internacional incorporada ao ordenamento jurídico brasileiro, não se lhes aplicando a regra do Direito Consuetudinário relativa à natureza dos atos praticados. Excepcionalmente, prevalecerá a jurisdição brasileira na hipótese de renúncia expressa à cláusula de imunidade jurisdicional". Os termos do verbete estão em consonância com o posicionamento do Supremo Tribunal Federal adotado no julgamento dos Recursos Extraordinários números 578543-MT e 597368-MT, pelo Tribunal Pleno em 15/5/2013 (DJE 27/05/2014). Ademais, ante da literalidade da Convenção sobre Privilégios e Imunidades das Nações Unidas, devidamente ratificada pelo Brasil por meio do Decreto $\mathrm{n}^{\circ}$ 27.784/50, é forçoso reconhecer que o Programa das Nações Unidas para o Desenvolvimento - PNUD, órgão diretamente ligado à ONU, goza de tal imunidade. Recurso de revista conhecido e provido. ${ }^{53}$ (grifos nossos)

Desta feita, tem-se que uma vez estipulada a imunidade em tratado internacional, esta deverá ser mantida pelos Estados, sob pena destes cometerem um ato antijurídico. Outrossim, necessário frisar que a imunidade poderá ser restrita caso esteja assim previsto em Convenção ou no caso da entidade renunciar a sua imunidade.

${ }^{51}$ Em relação aos Estados, o viés relativizado restou assentado no Brasil a partir do caso Geny de Oliveira $v$. República Democrática Alemã (RDA), em especial no voto de Rezek, então Ministro do STF. Cf. STF. Apelação Cível n. 9696-3/SP. Rel. Min. Sydney Sanches. Julgado em 31 mai. 1989 - Pleno. Publicado no DJ em 12 out. 1990.

52 STF. Recurso Extraordinário n. 578543/MT. Rel. Min. Ellen Gracie. Julgado em 15 mai. 2013 - Tribunal Pleno. Publicado no DJe em 26 mai. 2014.

53 TST. Agravo em Recurso de Revista n. 2718000320045020061. Rel. Min. Augusto César Leite de Carvalho. Julgado em 24 jun. 2015 - 6a Turma. Publicado no DEJT em 25 jun. 2015. 
Exemplos da primeira situação são encontrados normalmente em documentos constitutivos de instituições financeiras internacionais em razão da necessidade destas em adquirir a confiança dos credores, tal como previsto no Acordo do Banco Internacional para a Reconstrução e Desenvolvimento, nos Artigos do Banco Africano de Desenvolvimento e na Carta do Banco Asiático para o Desenvolvimento, os quais abarcam a possibilidade de ações judiciais serem contra si sejam propostas no território de seus membros ou onde tenham procurador constituído, em casos atinentes a empréstimos e garantia de apólices. ${ }^{54}$ Outras limitações quanto ao uso de imunidades fazem-se presentes em certos Tratados de Sede, como é o caso do acordo firmado entre o Reino Unido e o Banco Europeu para a Reconstrução e Desenvolvimento (BERD), em que há uma gama de benefícios não aplicáveis a ele ${ }^{55}$.

Em relação à renúncia das imunidades de jurisdição, seja para os atos funcionais da organização em si ou de seus funcionários, cumpre salientar que elas devem ser sempre expressas. ${ }^{56} \mathrm{O}$ encarregado em fazê-lo será a autoridade máxima da organização - no caso da ONU, por exemplo, trata-se de uma prerrogativa do Secretário-Geral ou, quando relativo a si, do Conselho de Segurança. ${ }^{57}$ Entretanto, oportuno salientar que a renúncia, via de regra, nunca compreenderá as medidas executivas ${ }^{58}$, de modo que apenas o julgamento do processo de conhecimento seria facultado aos Estados. ${ }^{59}$

${ }^{54}$ BANCO MUNDIAL. IBRD Articles of Agreement. 1944, Art. 7, seção 3; AFRICAN DEVELOPMENT BANK. Agreement Establishing the African Development Bank, 1964, Art. 52; ASIAN DEVELOPMENT BANK. ADB Charter. 1966, Art. 50(1). Cf. também: HUNTER, David B. International Financial Institutions and International Law. Hague: Kluwer, 2010, p. 105-106 e 124; SOARES, op cit.,p. 172-173 e 175 (para outros exemplos como no BID).

${ }^{55}$ Além das funções similares às outras instituições financeiras mencionadas, o BERD tampouco terá imunidades em casos atinentes a ações cíveis propostas por terceiros relativo à acidentes de trânsito causado por algum funcionário ou relativas à danos por lesão ou morte por sua omissão; bem como para ações que tenha contestado ou para executar laudo arbitral cujo processo tenha concordado em participar. BERD. Headquarters Agreement between the Government of the United Kingdom and the European Bank for Reconstruction and Development. 1991, Art. 4; HUNTER, op cit., p. 106-107.

56 ONU. Convenção sobre Privilégios e Imunidades das Nações Unidas. 1946, Art. 2, Seção 2. No mesmo sentido: ONU. Convenção sobre Privilégios e Imunidades das Agências Especializadas das Nações Unidas. 1947, Art. 2, Seção 4; SHAW, op cit., p. 1212; SOARES, op cit.,p. 176 (para outros exemplos como na ALALC).

${ }^{57}$ ONU. Convenção sobre Privilégios e Imunidades das Nações Unidas. 1946, Art. 5, Seção 20.

${ }^{58}$ Exceções a essa regra são raras e normalmente englobam instituições financeiras quando já há sentença acerca do conhecimento da ação prolatada (EVANS, Malcolm D. Internacional Law. $4^{\text {a }}$ ed. Oxford: Oxford University Press, 2014, p. 271). Outra rara exceção seria o caso Internacional Hotels Worldwide v. Grandvision Belgium, julgado pela Corte Civil de Bruxelas em 2011 sobre o pagamento de aluguéis do centro de comunicação de imprensa da OTAN no Kosovo, em que não só houve o julgamento no processo de conhecimento, como também houve a execução por não haver mecanismo interno na entidade para solucionar litígios atinentes a contratos privados (acerca disso, cf. o último ponto do presente texto), derrogando-se ambas as imunidades. REINISCH, August. The Privileges and Immunities of International Organizations in Domestic Courts. Oxford: Oxford University Press, 2013, p. 64.

59 ONU. Convenção sobre Privilégios e Imunidades das Nações Unidas. 1946, Art. 2, Seção 2. No mesmo sentido: ONU. Convenção sobre Privilégios e Imunidades das Agências Especializadas das Nações Unidas. 1947, Art. 2, Seção 4. 
Ao cabo, nota-se que em razão dos privilégios e imunidades as organizações internacionais não comporão o pólo passivo de muitas demandas no plano interno dos Estados. No entanto, isso não significa que essas entidades não cometem atos ilícitos, podendo igualmente ser aplicado a elas o instituto da responsabilidade internacional em razão da violação de uma obrigação geral de direito internacional, sendo esse o objeto de estudo na sequência do texto.

\section{A RESPONSABILIDADE DAS ORGANIZAÇÕES INTERNACIONAIS E OS ILC DRAFT ARTICLES DE 2011.}

O estudo da responsabilidade internacional das organizações internacionais tem sua origem nas discussões advindas na Comissão de Direito Internacional da ONU no ano de 2011 ao adotar-se um Draft Article sobre o tema - documento este que fora arquitetado com base em regras já existentes acerca da responsabilidade dos Estados, em que pese a grande diferença entre esses entes de/no direito internacional ${ }^{60}$. Por isso, a responsabilidade de uma organização vai ocorrer com base nos mesmos pressupostos em que as responsabilidades dos Estados são assentadas, ou seja, na existência de um ato ilícito imputável a um sujeito de direito internacional em razão de sua conduta ou omissão na ocorrência de um dano a outrem. $^{61}$

\footnotetext{
${ }^{60}$ Uma crítica sobre a adoção desse Draft com base nas regras atinentes aos Estados pode ser encontrado em: PELLET, Alain. International Organizations are definitely not States. In: RAGAZZI, Maurizio. Responsability of Internacional Organizations. Hague: Martinus Nijhoff Pub., 2013, p. 41. Crítica essa que encontra respaldo em outros documentos mais antigos, como: UN OFFICE OF LEGAL AFFAIRS. The UN as amicus curiae in Marvin R. Broadbent et al. v. OAS. United Nations Juridical Yearbook. Nova York, part III, pp. 220-242, 1980, p. 229. UN OFFICE OF LEGAL AFFAIRS. Memorandum to the Legal Adviser - UNRWA. United Nations Juridical Yearbook. Nova York, part II, pp.157-193, 1984, p. 188-189.

${ }^{61}$ VELASCO, op cit., p. 82; VERDROSS, Alfred. Derecho Internacional Público. $4^{\mathrm{a}}$ ed. Madrid: Aguilar, 1963 , p. 319.

${ }^{62}$ MELLO, Celso D. de Albuquerque. Responsabilidade Internacional do Estado. Rio de Janeiro: Renovar, 1995 , p. 06.

${ }_{64}^{63}$ MELLO (1974), op cit., p. 317.

${ }^{64}$ Note-se que as regras consuetudinárias cristalizadas a partir da jurisprudência (cujo ponto de partida é o caso Usina de Chorzow perante a Corte Permanente de Justiça Internacional julgado em 1927) e o Draft de 2001, considerados a base reguladora da responsabilidade internacional, lidam apenas com a responsabilidade dos Estados. Inclusive, acerca deste Draft, chama-se a atenção do ledor ao art. 57, o qual explicitamente afasta a possibilidade de as suas previsões serem aplicadas às organizações. ONU. Draft Articles on the Responsibility of States for Internationally Wrongful Acts. 2001; CARDOSO, Tatiana de A. F. R. A Responsabilidade
} 
Consequentemente, pode-se afirmar que essência da responsabilidade das organizações advém da sua personalidade jurídica, haja vista só ser possível que um ente seja responsabilizado quando ele detiver capacidade para atuar no plano das relações internacionais. Afinal, se uma entidade não for um sujeito que possua direitos e deveres distintos de seus membros, não seria possível imputar-lhe uma conduta ilícita em direito internacional (mas tão-somente àquele que seja revestido de capacidade).

Nesse sentido, como afirmado no início desse trabalho, o reconhecimento da personalidade jurídica de uma organização é importante para a legitimação de suas ações; porém, não apenas isso, ela é igualmente relevante para a sustentação da ordem na comunidade internacional haja vista a possibilidade de manter-se o equilíbrio e a própria justiça um corolário do instituto da responsabilidade ${ }^{62}$. Assim sendo, uma vez possuindo capacidade jurídica para atuar nas relações internacionais, as organizações poderiam acabar tendo imputada contra si alguma conduta ilícita em razão de suas condutas ou omissões. ${ }^{63}$

Para tanto, necessário a estipulação de parâmetros, os quais foram sedimentados no Draft Articles de $2011 .^{64}$ Seu objetivo, portanto, é apontar as situações em que organizações internacionais, ao transgredirem o direito internacional, podem ser responsabilizadas. ${ }^{65}$

De acordo com o artigo quatro, os elementos para a configuração de um ato ilícito cometido por uma organização internacional englobam a ocorrência de uma ação ou omissão que (a) vá de encontro com as obrigações internacionalmente assumidas pela organização e (b) lhe seja atribuível. ${ }^{66}$ Acerca do primeiro item, salienta-se que a conduta ilícita deve estar atrelada a algum ato ou omissão que não seja/esteja de acordo com as obrigações já assumidas pela entidade no plano externo ${ }^{67}$, sejam elas ligadas a uma regra de direito internacional geral vinculado aos seus fins ${ }^{68}$ ou algum compromisso específico perante aos seus membros. ${ }^{69}$

Internacional dos Estados como meio de efetivação dos Direitos Humanos. In: MENEZES, Wagner (org.). Estudos de Direito Internacional. Vol. XX. Curitiba: Juruá, 2010, p. 343-345.

65 ONU. Draft Articles on the Responsibility of International Organizations. 2011, art. 1 e 3.

${ }^{66}$ ONU. Draft Articles on the Responsibility of International Organizations. 2011, art. 4.

${ }^{67}$ Lembra-se que "a ilicitude é uma violação de uma norma internacional", excluindo-se aquelas de direito puramente doméstico. MELLO (1995), op cit., p. 32

${ }^{68}$ Inclui-se nesse escopo quaisquer regras de direito internacional (tratados, costumes, princípios, etc.), inclusive as regras de jus cogens. ONU. Draft Articles on the Responsibility of International Organizations. 2011, art. 41 (sobre jus cogens); ICJ. Interpretation of the Agreement of 25 March 1951 between the WHO and Egypt. Advisory Opinion publicada em 20 dez. 1980, pp. 89-90 . (tecendo que "as organizações internacionais são sujeitos de direito internacional e, como tal, estão vinculados por quaisquer obrigações de direito internacional geral, por seus atos constitutivos ou por acordos internacionais de que sejam parte").

${ }^{69}$ ONU. Draft Articles on the Responsibility of International Organizations. 2011, arts. 10, 11 e 12. 
No que tange o segundo, reporta-se a uma situação em que a organização esteja dirigindo e controlando a ação de (a) seus órgãos e/ou funcionários ${ }^{70}$, (b) um Estado, seus órgãos e/ou de seus agentes colocados à sua disposição ${ }^{71}$, (c) outra organização, seu órgãos e/ou de seus funcionários colocados à sua disposição) ${ }^{72}$, em direção ao cometimento de um ato ilícito, com o pleno conhecimento das conjunturas ilícitas e tal conduta. ${ }^{73}$ Além disso, são atribuíveis às organizações os atos adotados por seus órgãos e/ou funcionários em atividade oficial conforme os limites estatutários da organização ${ }^{74}$, mesmo na hipótese destes (a) excederem a autoridade da referida repartição, (b) ultrapassarem a competência do funcionário, ou (c) contrariarem as instruções repassadas para determinada missão. ${ }^{75}$

Ao lado da ocorrência de um ato ilícito e do nexo causal, para restar configurada a responsabilidade seria necessário a ocorrência de um dano, pois é um efeito sem o qual não há como veicular-se à obrigação de reparar. ${ }^{76}$ Acerca do conceito de prejuízo, esse abrangeria

[...] qualquer dano moral ou material originado de um ato internacional proibido [...]. No caso do dano material mais especificamente, ele seria aquele prejuízo causado diretamente ao bem jurídico que a norma externa protege. Por outro lado, o dano moral estaria ligado a uma lesão à honra e [à imagem do Estado, ou à] dignidade do ser humano. ${ }^{77}$

Logo, na ocorrência de um prejuízo de ordem material ou moral advindo de um ato ilícito cometido pela organização direta ou indiretamente, nasce o dever de reparar de forma plena e adequada aquele que o sofrera. ${ }^{78}$ Dentre as medidas encontradas para abrandar a lesão estão a restituição, a compensação e a satisfação, aplicadas conjunta ou separadamente, no intuito de fazer a entidade refletir acerca de sua conduta em prol do respeito para com a normativa internacional. ${ }^{79}$ Ademais, para além da justa reparação, há também a obrigação de cessar o ato danoso no caso deste persistir e/ou de oferecer garantias apropriadas de nãorepetição se necessário a partir das circunstâncias do caso. ${ }^{80}$

${ }^{70}$ ONU. Draft Articles on the Responsibility of International Organizations. 2011, art. 6.

${ }^{71}$ ONU. Draft Articles on the Responsibility of International Organizations. 2011, art. 7.

${ }^{72}$ ONU. Draft Articles on the Responsibility of International Organizations. 2011, art 7.

${ }^{73}$ ONU. Draft Articles on the Responsibility of International Organizations. 2011, art. 15.

${ }^{74}$ Acerca disso, importante frisar que mesmo agindo dentro de seus fins, se essa conduta gerar um dano e violar alguma obrigação internacional assumida pela organização, ela será responsabilizada, haja vista não ser possível excluir a responsabilidade com base no direito institucional. ONU. Draft Articles on the Responsibility of International Organizations. 2011, art. 32.

${ }_{76}$ ONU. Draft Articles on the Responsibility of International Organizations. 2011, art. 8.

${ }^{76}$ MELLO (1995), op cit., p. 51.

${ }_{77}^{77}$ CARDOSO, op. cit., p. 345.

${ }^{78}$ ONU. Draft Articles on the Responsibility of International Organizations. 2011, art. 31; PCIJ. Factory of Chorzow (Germany vs. Poland). Jurisdiction. Julgado em 26 de julho de 1927, p.21 (muito embora ligado à responsabilidade estatal, o dever de reparar na ocorrência de um prejuízo é um entendimento costumeiro).

${ }^{79}$ ONU. Draft Articles on the Responsibility of International Organizations. 2011, arts. 34, 35, 36 e 37.

${ }^{80}$ ONU. Draft Articles on the Responsibility of International Organizations. 2011, art. 30. 
A grande questão, entretanto, não são apontar os elementos que compõe a responsabilidade internacional das organizações internacionais, mas sim o local que aplicará tais regramentos. Isso porque, não existe uma Corte Internacional formalmente constituída com jurisdição exclusiva para receber denúncias de Estados (ou indivíduos) que tenham sofrido algum tipo de dano advindo da conduta ou da omissão de uma organização.

E no que tange àquelas já existentes e de cunho permanente, as suas competências são bem limitadas. Por exemplo, as organizações internacionais não têm competência jurisdicional perante a Corte Internacional de Justiça, mas tão-somente consultiva e desde que ligadas à sua estrutura, como as agências especializadas. ${ }^{81} \mathrm{Na}$ Corte Interamericana de Direitos Humanos a jurisdição contenciosa é adstrita a casos que contenham denúncias de violação da Convenção Americana de Direitos Humanos por um Estado-parte desse documento, submetidos por (a) Estados-membros da OEA, isto é, por países do continente americano que tenham ascendido à OEA, incluindo-se qualquer entidade política oriunda da união de seus Estados-membros que tenha ratificado à Carta da OEA, e que tenham reconhecido a sua jurisdição ou (b) pela Comissão Interamericana, a qual representa os interesses de particulares. ${ }^{82}$

Ao seu turno, para assuntos interestatais, a Corte Europeia de Direitos Humanos é competente para ouvir casos submetidos por qualquer parte contratante da Convenção Europeia de Direitos Humanos por violação cometida por outra parte contratante. ${ }^{83}$ Ademais, é competente para receber petições de qualquer pessoa singular, organização não governamental ou grupo de particulares que se considere vítima de violação dos direitos reconhecidos na Convenção ou nos seus protocolos por qualquer um dos membros da Convenção Europeia. ${ }^{84}$

${ }^{81}$ ONU. Carta das Nações Unidas. 1945, art. 96; ONU. Estatuto da Corte Internacional de Justiça. 1945, art. 34.

${ }^{82}$ OEA. Carta da Organização dos Estados Americanos. 1948, arts. 4 e 5; EA.

${ }^{83}$ UNIÃO EUROPEIA. Convenção Europeia de Direitos Humanos. 1950, art. 33.

${ }^{84}$ UNIÃO EUROPEIA. Convenção Europeia 1969 [no Brasil, Dec. 678/92], arts.44, 45, 61, 62 e 64. de Direitos Humanos. 1950, art. 34. 
Por conseguinte, nota-se desses exemplos que há pouquíssimo espaço para a participação das organizações internacionais em contendas internacionais em órgãos préconstituídos. $^{85}$ De fato, esse panorama só não é mais negativo em razão da existência de Tribunais Arbitrais $a d h o c^{86}$ e da própria Corte Permanente de Arbitragem, sediada em Haia, na Holanda, que é bastante citada em acordos de sede e documentos constitutivos de algumas organizações como sendo o tribunal competente para dirimir questões atinentes à sua atividade. ${ }^{87} \mathrm{Ou}$, ainda, os tribunais instituídos no seio das próprias organizações, particularmente naquelas classificadas como universais, cujos exemplos são o Tribunal Administrativo das Nações Unidas, o Tribunal Administrativo da Organização Internacional do Trabalho e o Tribunal Administrativo do Fundo Monetário Internacional. ${ }^{88}$

\footnotetext{
${ }^{85}$ Acerca disso, importante destacar a tentativa da Faculdade de Direito da Universidade Federal de Santa Maria (FADIMSA) em peticionar no ano de 2011 à Comissão Interamericana de Direitos Humanos da OEA em face da ONU, pedindo a responsabilização da mesma em razão de mortes e danos causados por um surto de cólera no Haiti potencialmente causados pelos capacetes-azuis servindo à Missão da ONU para o Haiti (MINUSTAH). Na sua argumentação, em razão da impossibilidade de a ONU figurar no polo passivo da ação por não ser um Estado e tampouco uma entidade formada apenas por membros da OEA, teceu que a ONU teria se sub-rogado nos direitos do Estado haitiano, logo, podendo responder em seu lugar pelas violações/omissões ocorridas - o que, todavia, não encontra amparo legal ou costumeiro. Cf. FADISMA. Denúncia à Comissão Interamericana de Direitos Humanos. Out. 2011. Disponível em: 〈http://s.conjur.com.br/dl/haiti-denuncia-onu-oea.pdf〉. Acesso em 13 ago. 2015.
}

${ }^{86}$ Exemplos desse caso são as previsões contidas no acordo de sede firmado entre a UNESCO e a França e a ONU e os Estados Unidos. UNESCO. Agreement between France and UNESCO regarding its Headquarters and the Privileges and Immunities of the Organization on French Territory. 1954, art. 29; TRIBUNAL DE GRANDE INSTANCE DE PARIS. UNESCO v. Boulois. Revue de l'arbitrage. Paris, 1999, p. 343 (afastando a imunidade da UNESCO e reforçando a obrigatoriedade da arbitragem); ONU. Agreement between the UN and the USA regarding the Headquarters of the UN. 1947, seção 21; ICJ. Applicability of the Obligation to Arbitrate under Section 21 of the United Nations Headquarters Agreement of 26 June 1947. Advisory Opinion publicada em 26 abr. 1988, pp. 33 (atestando a obrigatoriedade da cláusula arbitral à ONU).

${ }^{87}$ São exemplos o acordo de sede firmado entre a Organização para a Proibição de Armas Químicas e a Holanda em 1997, o acordo de sede firmado entre a Organização de Polícia Internacional e a França em 2009, o acordo de sede firmado entre o Banco Asiático de Desenvolvimento e as Filipinas em 1966, a Convenção Constitutiva da Organização Europeia de Telecomunicações via Satélite de 1982, a Convenção Constitutiva da Organização para a Exploração de Satélites Meteorológicos de 1983 e a Convenção Constitutiva da Organização Europeia de Pesquisa Astronômica no Hemisfério Sul de 1962. PCA. Multilateral Treaties. s/d. Disponível em: <http://www.pca-cpa.org/showpage890a.html?pag_id=1389>. Acesso em 13 ago. 2015; PCA. Other Agreements and Instruments. $\mathrm{s} / \mathrm{d}$. Disponível em: <http://www.pcacpa.org/showpage31a4.html?pag_id=1390>. Acesso em 13 ago. 2015.

${ }^{88}$ GAILLARD, Emmanuel; PINGEL-LENUZZA; Isabelle. International Organizations and Immunity from Jurisdiction. International \& Comparative Law Quarterly. Oxford, v. 51, n. 1, pp. 1-15, 2002, p. 11. 
A partir do exposto, entende-se que no caso de uma organização internacional cometer ou se abster de evitar um ato ilícito relativo as suas obrigações internacionalmente constituídas, ela só será julgada por uma corte internacional quando essa apresente jurisdição sobre a entidade - o que é raro.

Quer isso dizer que, excepcionados os casos existentes em tribunais administrativos, via de regra, a organização não é responsabilizada. Ocorre que essas entidades tampouco serão julgadas no plano doméstico dos países em razão dos privilégios e imunidades anteriormente examinados.

Nesse interim, é preciso destacar que os privilégios e imunidades não podem ser entendidos como uma carte blanche às organizações, de modo que elas possam levar à cabo todas e quaisquer atividades mesmo que ligadas aos seus objetivos ou, inclusive, absterem-se de tomar medidas apropriadas para evitar que direitos protegidos por elas conforme suas finalidades sejam violados. Na verdade, os benefícios concedidos às entidades por meio dos privilégios e imunidades serviriam para que elas desempenhassem as suas atividades de forma independente, sem serem controladas pelos Estados-membros - somente isso, de modo que as regras gerais de direito internacional sempre fossem observadas ao concretizarem as suas atividades.

Portanto, considerando a noção de justiça que permeia toda e qualquer relação jurídica, não seria possível aceitar que as organizações internacionais não possam ser responsabilizadas por suas condutas outrora estipuladas ao ultrapassarem os limites legais gerais em função da inexistência de um tribunal internacional propício para realizar tal julgamento ou, especialmente, por força da sua imunidade funcional no interior dos Estados. Noutros termos, não seria admissível que essas entidades somente fossem julgadas quando existissem tribunais internacionais específicos (frequentemente inacessíveis aos indivíduos em causas comuns) ou quando renunciassem as suas imunidades no plano doméstico dos Estados, devendo haver outros mecanismos para que os Estados pudessem exercer a sua jurisdição perante tais sujeitos na ocorrência de uma violação do direito internacional geral atribuída a eles a fim de enfatizar o respeito à tais regras.

Nessa linha, surgem duas possibilidades no direito internacional quanto à viabilidade das cortes domésticas em ouvir casos quando da violação de uma regra por parte de uma organização internacional: (a) na hipótese de inexistir um mecanismo para solução de litígios no ambiente orgânico da própria entidade; e (b) no caso da organização ultrapassar os limites de suas funções - possibilidades essas que serão trabalhadas no item a seguir. 


\section{AS POSSÍVEIS FORMAS DE OBTER-SE REPARAÇÃO PARA VÍTIMAS DE TRANSGRESSÕES DE ORGANIZAÇÕES INTERNACIONAIS E OS SEUS LIMITES.}

O direito internacional, observando a crescente atividade das organizações internacionais e o consequente aumento de omissões e violações de obrigações internacionais cometidas por essas entidades quando levando a cabo as suas finalidades, tem buscado outras possibilidades para que as vítimas dessas transgressões recebam uma justa reparação. Assim, surgem teorias que buscam sanar essa lacuna do ordenamento jurídico internacional, a fim de que as organizações possam responder por suas condutas com a mesma facilidade que lhes é permitido pleitear reparações por prejuízos sofridos direta ou indiretamente por $\mathrm{si}^{89}$.

Dentre essas teses, a primeira que se destaca é a possibilidade de cortes domésticas exercerem jurisdição sobre as organizações internacionais quando da inexistência de outro meio adequado no seio da entidade para a solução do litígio envolvendo a violação de uma regra a ela atribuída, afastando-se a imunidade de jurisdição e outros eventuais privilégios. Esse é um entendimento que advém de uma construção envolvendo a ONU, pautado em uma opinião da Corte Internacional de Justiça do ano de 1953, entendendo-se que essa organização, em razão de seus objetivos em promover a liberdade e a justiça para os indivíduos, não poderia privar os seus funcionários de um meio judicial ou arbitral para resolver as eventuais disputas atinentes às suas relações. ${ }^{90}$

Em que pese essa opinião não "falar em uma obrigação jurídica imposta à ONU para criar um tribunal administrativo", ela trabalha com a impossibilidade de denegar-se a justiça sentido que tem sido levado a cabo nas decisões proferidas no Tribunal Administrativo da OIT quanto a reclamações funcionários internacionais de entidades que aceitaram a jurisdição desse tribunal ${ }^{91}$ e no Tribunal Administrativo da ONU no que tange a necessidade de aceitar-

\footnotetext{
${ }^{89}$ Cf. parte 1 desse texto quanto a personalidade jurídica das organizações, em especial o comentário atinente à opinião da Corte Internacional de Justiça no caso Bernadotte, que é claro no sentido de a ONU ser capaz de pleitear reparações.

${ }^{90}$ ICJ. Effect of Awards of Compensation Made by the United Nations Administrative Tribunal. Advisory Opinion publicada em 21 dez. 1953, pp. 57.

91 São os casos Chadsey [1968] e Rubio [1997]. REINISCH, August. The immunity of international organizations and the jurisdiction of their administrative tribunals. Chinese Journal of International Law. Oxford, v. 7, n. 2, pp. 285-306, 2008, p. 287.
} 
se à cláusula arbitral quando prevista em tratado, até mesmo em contratos firmados com indivíduos comuns (isto é, em contratos privados) ${ }^{92}$.

Esse posicionamento encontra respaldo também na Corte Europeia de Direitos Humanos nos casos Waite e Kennedy v. Alemanha e Beer e Regan v. Alemanha, onde se debateu a possível violação pelo Estado alemão da regra contida no artigo 6(1) da Convenção Europeia de Direitos Humanos, referente ao direito a um julgamento justo ao conceder imunidade à Agência Espacial Europeia. Nesses casos, a Corte Europeia ponderou no sentido de a imunidade depender da existência de um processo de revisão no âmbito interno da organização, como é a existência do Appeals Board da referida entidade, motivo pelo qual a Corte julgou em favor da Alemanha. ${ }^{93}$

Ademais, conforme levantamento realizado por Young, tal disposição tem sido aplicada no plano doméstico dos Estados:

\begin{abstract}
Em 2005, o Tribunal de Cassação francês negou a imunidade para o Banco Africano de Desenvolvimento, apesar de disposição convencional, porque "a ausência de quaisquer tribunais estabelecidos dentro do Banco Africano de Desenvolvimento [...] faz com que seja impossível para o trabalhador exercer o seu direito de ter uma instância para considerar seu caso". Mais recentemente, em três casos julgados em 21 de dezembro de 2009, o Tribunal de Cassação belga, aplicando o raciocínio da $\mathrm{CEDH}$, negou a imunidade às organizações internacionais, devido à falta de um fórum alternativo razoável. São os casos do Secretariado-Geral do Grupo de Estados do Caribe e do Pacífico v. Lutchmaya, Secretariado-Geral do Grupo de Estados do Caribe e do Pacífico S v. BD, em que a referida organização não dispunha de qualquer mecanismo de solução de controvérsias. ${ }^{94}$
\end{abstract}

Essa posição foi replicada, ainda, pela Corte Suprema Argentina em algumas ocasiões, como no caso Fibraca Constructora v. Comissão Técnica Mista de Salto Grande de 1993, mantendo-se a imunidade dessa organização perante as cortes locais por existir na estrutura organizacional da referida entidade o Tribunal Arbitral Internacional de Salto Grande, e afastando-se, por isso, a possível violação do acesso a justiça previsto na Constituição Argentina $^{95}$; bem como no caso Duhalde v. Organização Panamericana de Saúde de 1999, ao denegar-se o pedido da parte em razão da possibilidade de a mesma em peticionar ao Tribunal

Administrativo da OIT, em que pese não citar a jurisprudência internacional no seu teor ${ }^{96}$.

92 TRIBUNAL ARBITRAL DA ONU. Teixeira v. Secretário-Geral da ONU. Julgamento n. 230 de 14 out. 1977 (concedendo indenização à parte em razão da demora em instituir-se o procedimento arbitral, previsto no contrato firmado).

${ }^{93}$ CRAWFORD, op cit., p. 175; ECHR. Beer and Regan v. Germany. Caso no. 28934/95. Julgado em 18 fev. 1999, pp. 59; ECHR. Waite and Kennedy v. Germany. Caso no. 26083/94. Julgado em 18 fev. 1999, pp. 68. 94 YOUNG, Aron L. Deconstructing International Organization Immunity. Georgetown Journal of International Law. Washington D.C., v. 44, pp. 311-364, 2012, p. 358-359.

${ }_{95}$ MARTHA, Rutsel Silvestre J. International Financial Institutions and Claims of Private Parties: immunities obliges. In: CISSÉ, Hassane; BRADLOW, Daniel D.; KINGSBURY, Benedict. The World Bank Legal Review. Vol. 3. Washington D.C.: IBRD, 2012, p. 119-120.

${ }^{96}$ REINISCH (2013), op cit., p. 23. 
Logo, nota-se que há uma tendência no plano internacional em relativizar a imunidade da organização quando não existir um órgão que possa julgar o pleito de maneira adequada. Apesar disso, necessário referir que não existe uma regra consuetudinária formada até o momento justamente pelo fato de haver casos em que a ação foi rechaçada no plano doméstico, mesmo não havendo outro remédio possível.

Trata-se, por exemplo, do caso Mothers of Srebrenica, recentemente julgado pela Corte Europeia de Direitos Humanos. ${ }^{97}$ Essa foi uma ação proposta na Holanda contra a ONU por familiares de vítimas do massacre ocorrido no ano de 1995 em Srebrenica, cidade situada dentro do que era considerado uma zona segura na Bósnia pela ONU, haja vista a falha dessa organização em assegurar o bem-estar daqueles que lá moravam por intermédio das suas forças de paz (a UN Protection Force - UNPROFOR, cujos capacetes-azuis eram holandeses), não tendo impedido a morte de mais de 7.000 bósnios-muçulmanos na ocasião de um ataque perpetrado pelas forças sérvias.

Nesse caso, a ação foi considerada improcedente no plano interno em razão da imunidade de jurisdição da organização, ensejando a propositura de nova ação perante a Corte Europeia de Direitos Humanos, alegando-se a violação do supracitado artigo 6(1), em razão da inexistência de outro mecanismo para a efetiva reparação. Entretanto, a Corte Europeia de Direitos Humanos não seguiu a argumentação exarada nos casos contra a Alemanha do ano de 1999 mencionados anteriormente, tecendo que a inércia da ONU quanto a uma efetiva reparação até o momento não seria motivo suficiente para que a Holanda pudesse levantar a imunidade da organização. ${ }^{98}$ Ademais, citou que não havia na demanda um pedido para averiguar a violação de obrigação internacional por parte da ONU e, mesmo se houvesse, ela não poderia interpretar os dispositivos da Carta da ONU ou determinar a omissão por parte da UNPROFOR sem o próprio Conselho de Segurança ter se manifestado sobre ao tema.

Assim, não se pode afirmar que, hodiernamente, na inexistência de um tribunal no seio da organização ela obrigatoriamente terá a sua imunidade levantada, visto que não existe uma obrigação costumeira em direito internacional que assim exija, a não ser em casos onde tais

\footnotetext{
${ }^{97}$ ECHR. Stichting Mothers of Srebrenica and Others v. the Netherlands. Caso no. 65542/12. Julgado em 11 jun. 2013.

${ }_{98}$ Cabe referir que existem casos em que a ONU realizou o pagamento de indenizações às vítimas por prejuízos causados pelo cometimento de atos ilícitos. São exemplos os tratados firmados entre a ONU e o Congo no ano de 1961 (por danos causados a civis congolenses pelos capacetes azuis, sobretudo, agindo de modo "nãooficial") e entre ONU e Bélgica em 1965 (por danos causados à nacionais belgas que estavam no Congo), ambos atinentes às operações onusianas no Congo, por meio da ONUC, a qual foi estabelecida pela Resolução n. 143 do Conselho de Segurança em 1960, durando até 1964. VELASCO, op cit., p. 83; SIMMONDS, R. Legal problems arising from the United Nations military operations in the Congo. Hague: Martinus Nijhoff Pub., 1968, p. 231-235.
} 
mecanismos de solução de litígios (administrativos ou arbitrais) sejam previstos em tratado. Outrossim, quando analisados os casos, nota-se que a matéria abarcada pelos mesmos influencia diretamente na decisão de desconsiderar a imunidade de uma organização - o que, no entanto, não afasta por completo essa possibilidade.

A segunda hipótese para a obtenção de reparação para vítimas de transgressões de organizações internacionais diz respeito a atos ultra vires, ou seja, abarca os casos em que as entidades ultrapassam os limites de suas funções. Essa teoria tem como base a própria natureza das imunidades das organizações, qual seja, a funcional, cuja atribuição decorre das funções que serão desempenhadas por elas nos limites formais prescritos em seus documentos constitutivos. Logo, quando agindo para além dos limites pelas quais foram criadas (isto é, ultra vires), as organizações poderiam ser responsabilizadas, pois perderiam os seus privilégios e imunidades.

No entendimento de Reinisch e Weber, as organizações internacionais só agiriam de duas formas - de maneira oficial ou ultra vires, fazendo com que as suas imunidades dependam da atividade levada a cabo para serem confirmadas. ${ }^{99}$ Para tanto, explicam que

\begin{abstract}
[a]o contrário dos Estados, a capacidade jurídica internacional das organizações internacionais é geralmente considerada limitada. Noutros termos, as organizações internacionais têm personalidade jurídica apenas nos limites necessários para realizar as suas funções. Legalmente, elas são incapazes de agir para além de sua personalidade funcional. Quaisquer atos não cobertos por tal capacidade limitada são ultra vires. Ao mesmo tempo, as organizações internacionais percebem imunidade funcional, cobrindo atos realizados quando levando a cabo as suas funções. Já que as organizações internacionais só podem operar dentro do escopo de sua personalidade funcional, não há espaço para atos não-funcionais, aos quais a imunidade seria negada. ${ }^{100}$
\end{abstract}

Nesse mesmo viés, Fox e Webb sugerem a adoção de um 'Teste de Funcionalidade' para, então, concluir-se se certo ato foi ou não necessário para o efetivo funcionamento da

\footnotetext{
99 REINISCH, August; WEBER, Ulf Andreas. In The Shadow of Waite and Kennedy: the jurisdictional immunity of international organizations, the individual's right of access to the courts and administrative tribunals as alternative means of dispute settlement. International Organizations Law Review. Leiden, n.1, pp. 59-110, 2004, p. 63.

100 Ibid., p. 63-64..

${ }^{101}$ FOX; WEBB, op cit., p. 575.
} 
organização. ${ }^{101}$ Caso afirmativo, a imunidade deveria ser mantida por cortes domésticas; porém, se negativo, a imunidade poderia ser levantada. Para concluírem acera da necessidade do referido teste, os autores partem da análise do caso Laboratório Europeu de Biologia Molecular v. Alemanha, julgado por um Tribunal Arbitral ad hoc do ano de 1997, em que a grande discussão deu-se em torno da possiblidade de o Estado aplicar determinados impostos à entidade, os quais afetariam largamente os recursos financeiros da mesma. $\mathrm{Na}$ decisão, o tribunal teceu que, no termo do Acordo de Sede firmado entre a organização e a Alemanha, as isenções fiscais limitar-se-iam às atividades oficiais do laboratório, não incidindo em valores relativos à alimentação ou acomodação e, por conseguinte, que o Estado poderia sim cobrar tais impostos. ${ }^{102}$

Aliás, em que pese os atos ultra vires não dizerem respeito à falta de uma estrutura que possa julgar certa demanda no âmbito das organizações, mas da possibilidade de restringir-se a imunidade dessas entidades quando envolvendo atos perpetrados por seus órgãos e funcionários para além das funções estabelecidas em seus estatutos e contratos, esse julgado expõe a ideia de que os "meios internos", quando previstos, é que devem verificar se a organização violou direta ou indiretamente as suas atribuições.

Quer isto dizer que essa hipótese segue o raciocínio da proposição anterior, de modo que só permitir-se-ia a derrogação da imunidade por tribunais locais quando não houvesse outro meio para auferir uma justa reparação aos demandantes, seja ela institucional ou arbitral $a d h o c$ - instâncias essas em que a organização implicitamente renunciou a sua imunidade de jurisdição $^{103}$. Assim, aqueles que sofrerem prejuízos pelo descumprimento de obrigação por parte de certa organização podem buscar a jurisdição interna dos países na tentativa de demonstrar que a violação decorreu de uma ação extrafuncional caso não haja outro mecanismo disponível.

\footnotetext{
102 Ibid., p. 575-576; REINISCH, August. International Organizations before National Courts. Cambridge: Cambridge University Press, 2004, p. 241.

103 A conclusão de que as organizações internacionais renunciam tacitamente a sua imunidade frente a esses tribunais foi decidida em International Tin Council v. Amalgamet Inc. - caso de 1988 iniciado em razão da empresa ter proposto uma ação em corte arbitral nos Estados Unidos contra a organização, tal como previsto no contrato firmado entre as partes, por essa não ter honrado três contratos de compra de tin. A organização alegou que ela era imune e que a previsão contratual relativa a arbitragem não era forceable, o que foi afastado pela Corte Suprema do condado de Nova York. RATNER, Steven R. International Tin Council v. Amalgamet Inc. 524 N.Y.S.2d 971. American Journal of International Law. Washington D.C., v. 82, n. 4, pp. 837-840, out. 1988.
} 
Contudo, essa possibilidade gera discussões no sentido de quem deteria a capacidade para pronunciar se o ato perpetrado pela organização internacional estava alinhado às suas funções ou não. A jurisprudência tende a considerar que cabe a própria organização ponderar sobre os seus atos, como visto no julgamento de inadmissibilidade do caso Mothers of Srebrenica, acima referido, em que a Corte Europeia de Direitos Humanos teceu que não lhe tocaria analisar os atos da UNPROFOR. ${ }^{104}$ A Corte Internacional de Justiça, em seu parecer sobre certas despesas da ONU em 1962, manifestou-se similarmente no sentido de que a organização, ao adotar medidas com a crença de que as mesmas foram adequadas para o cumprimento de seus propósitos, não agira ultra vires, logo, competindo a si tal apreciação. ${ }^{105}$

Não obstante, essa posição não parece ser propícia ao notar que competiria à própria organização determinar a sua responsabilidade, ao passo que, caso concluísse que a sua ação excedera os seus propósitos, ela estaria assumindo a culpa por um determinado ato, corroborando para a sua própria condenação. Outrossim, essa responsabilização "natural” advinda da culpabilidade já ter sido reconhecida tampouco condiz com a prática internacional no que tange a responsabilização das organizações internacionais. ${ }^{106}$

\footnotetext{
${ }^{104}$ ECHR. Stichting Mothers of Srebrenica and Others v. the Netherlands. Caso no. 65542/12. Julgado em 11 jun. 2013.

${ }^{105}$ ICJ. Certain Expenses of the United Nations (Article 17, paragraph 2, of the Charter). Advisory Opinion publicada em 20 jul. 1962, pp. 21 .

${ }^{106}$ Apesar de serem casos onde resta evidente a ocorrência de atos omissivos e comissivos da ONU (e não ultra vires), dois julgados da Corte Europeia de Direitos Humanos corroboram para esse entendimento. Em Behrami e Behrami v. França e Saramati v. França, Alemanha e Noruega, afirmou-se que a ONU é quem estava dirigindo e controlando de maneira geral as operações da K-FOR (operação de segurança levada a cabo pela Organização do Tratado do Atlântico Norte no Kosovo) e da UNMIK (órgão da ONU com poderes administrativos interinos para a região do Kosovo), por intermédio da autorização concedida pelo Conselho de Segurança através da Resolução n. 1244 de 1999 - ações essas que levaram a morte de Gadaf Behrami e deixaram Bekir Behrami cego em razão da desinformação quanto a existências de minas terrestres em determinada região; bem como conduziram à prisão arbitrária e prolongada de Ruzhdi Saramati. Nem por isso ações contra a ONU no plano doméstico dos Estados reivindicando a sua responsabilização já confirmada pela Corte Europeia foram propostas. ECHR. Behrami \& Behrami vs. France / Saramati vs. France, Germany \& Norway. Casos no. 71412/01 e 78166/01. Julgados em 02 mai. 2007.
} 
Logo, seria necessário aprimorar o entendimento de que as organizações não poderiam verificar os seus próprios atos, deixando esse controle ser realizado por outra instituição de modo que proteções procedimentais, como a independência e a imparcialidade do órgão julgador, restassem evidentes. Ao menos, as cortes domésticas belgas já sinalizaram em sentido análogo no caso Western European Union v. Siedler no ano de 2009, decidindo-se por denegar a imunidade à entidade em razão da existência de preocupações atinentes aos procedimentos internos (como a independência) adotados por esta. ${ }^{107}$

Com isso, pode-se afirmar que essas duas hipóteses são possiblidades palpáveis para que as organizações internacionais ofereçam justas reparações àqueles que sofreram prejuízos em razão de atos ou omissões causados por essas entidades direta ou indiretamente, quando conduzindo (ou não) as finalidades previstas nos tratados constitutivos das mesmas. Afinal, com esses mecanismos, restringem-se as formas de o acesso à justiça ser obstado pelas organizações por intermédio da alegação de imunidade funcional, impulsionando que as mesmas regulem mais os atos que seus órgãos e funcionários levam a cabo.

\section{CONSIDERAÇÕES FINAIS}

O presente artigo tinha como objetivo central debater novas possibilidades de responsabilização das organizações internacionais, haja vista um dos impactos mais notórios do surgimento dessas entidades enquanto sujeitos de direito internacional ser a alegação de imunidade funcional perante as cortes domésticas na ocorrência de um prejuízo causado por um ato ilícito perpetrado direta ou indiretamente por elas quando executando as suas atividades-fim, a qual tem impedido a adoção de justas reparações.

Isso porque, mesmo violando o direito internacional, as organizações não são rotineiramente responsabilizadas por suas condutas antijurídicas, de modo que não existe até então, um meio considerado eficaz para manter-se o equilíbrio e a própria justiça na comunidade internacional quando envolvendo a atividade dessas entidades - excepcionados os casos em que elas pagam espontaneamente algum montante a título de compensação, aceitam a jurisdição dos países (mesmo não havendo possibilidade de execução) ou tenham estabelecido em sua estrutura orgânica formas de garantir a reparação.

${ }^{107}$ YOUNG, op cit., p. 359. 
Para debater o tema, por conseguinte, em um primeiro momento, o texto voltou-se à explicação do porquê as organizações internacionais podem hodiernamente atuar no plano internacional, apontando que a atribuição da personalidade jurídica às mesmas, seja ela de forma explicita ou implícita, é fundamental para que essas entidades tenham direitos e deveres frente à sociedade internacional. Posteriormente, pontuou-se a garantia de certos privilégios e imunidades às organizações a fim de que elas possam levar a cabo as atividades préestabelecidas em seus documentos constitutivos, de forma independente e apropriada, sem a intromissão dos seus Estados-membros.

$\mathrm{Na}$ sequência detalhou-se a possibilidade de as organizações internacionais serem responsabilizadas pelos prejuízos de ordem moral ou material causados a outrem em razão do cometimento direto ou indireto de um ato que viola uma obrigação geral de direito internacional a ela apontada. Entretanto, nesse item igualmente expôs-se as dificuldades atinentes à indicação de um órgão judicial competente para julgar ações propostas contra organizações internacionais, ressaltando-se, em vista disso, a existência de mecanismos internos encontrados na estrutura orgânica dessas entidades e a utilização foros arbitrais como espaços capazes para ouvir tais casos.

Ao cabo, delinearam-se duas hipóteses para se afastar as imunidades das organizações internacionais em cortes domésticas pela violação de uma regra de direito internacional, quais sejam, na inexistência de um mecanismo para solução de litígios no ambiente orgânico das organizações ou outro qualquer previsto em tratado, e no caso das entidades ultrapassarem os limites de suas funções, agindo para além dos objetivos pelas quais foram edificadas. Proposições essas que se pautam pelo direito humano de acesso a justiça, subdividido no direito à revisão judicial e na existência de procedimentos equitativos, os quais deveriam ser observados por todos aqueles que atuam nas relações internacionais - inclusive as organizações.

Afinal, as imunidades das organizações são restritas às funções por elas realizadas, devidamente delineadas no momento de sua edificação, não pendendo ser confundidas com uma autorização ampla e sem nenhum tipo de controle. Em razão disso, tais conjecturas podem ser vistas como contornos plausíveis e palpáveis a essas imunidades, de modo que a devida responsabilização dessas entidades ocorra ao agirem ilicitamente ou omitirem-se na realização de suas atividades, causando prejuízos à outrem. 


\section{REFERÊNCIAS}

AFRICAN DEVELOPMENT BANK. Agreement Establishing the African Development Bank, 1964. Disponível em: <http://www.afdb.org/fileadmin/up loads/afdb/Documents/Legal-Documents/Agreement\%20Establishing\%20the \%20ADB\%20final\%202011.pdf>. Acesso em 11 ago. 2015.

ASIAN DEVELOPMENT BANK - ADB. ADB Charter. 1966. Disponível em: <http://www.adb.org/sites/default/files/institutional-document/32120/charter.p df >. Acesso em 11 ago. 2015.

AMERICAN SOCIETY OF INTERNATIONAL LAW - ASIL. Notes on Legal Questions concerning the United Nations. The American Journal of International Law. Washington D.C., v. 42, n. 2, pp. 445-447, abr. 1948.

BANCO MUNDIAL. IBRD Articles of Agreement. 1944. Disponível em: $<$ http://siteresources.worldbank.org/EXTABOUTUS/Resour ces/ibrdarticlesofagreement.pdf>. Acesso em 10 ago. 2015.

BENJAMIN, Daniela Arruda. A Aplicação dos Atos de Organizações Internacionais no Ordenamento Jurídico Brasileiro. Brasília: FUNAG, 2014.

BANCO EUROPEU PARA RECONSTRUÇÃO E DESENVOLVIMENTO - BERD. Headquarters Agreement Between the Government of the United Kingdom and the European Bank for Reconstruction and Development. 1991. Disponível em: <http://www.evropa.gov.rs/Documents/Entity>. Acesso em 11 ago. 2015.

BULL, Hedlet A Sociedade Anárquica: um estudo da ordem na política mundial. Brasília: Editora UnB, 2002.

CAMPOS, João Mota de. Organizações Internacionais: teoria geral. $3^{\mathrm{a}}$ ed. Curitiba: Juruá, 2010.

CANÇADO TRINDADE, Antônio Augusto. Direito das Organizações Internacionais. Belo Horizonte: Del Rey, 2002.

CARDOSO, Tatiana de A. F. R. A Responsabilidade Internacional dos Estados como meio de efetivação dos Direitos Humanos. In: MENEZES, Wagner (org.). Estudos de Direito Internacional. Vol. XX. Curitiba: Juruá, 2010. 
CARNEIRO, Cynthia S. O Direito da Integração Regional. Belo Horizonte: Del Rey, 2007. CRAWFORD, James. Brownlie's Principles of Public International Law. $8^{\mathrm{a}}$ ed. Oxford: Oxford University Press, 2012.

DI PIETRO, Maria Sylvia Z. Direito Administrativo. 15ª ed. São Paulo: Atlas, 2003.

EUROPEAN COURT OF HUMAN RIGHTS - ECHR. Beer and Regan v. Germany. Caso no. 28934/95. Julgado em 18 fev. 1999.

Behrami \& Behrami vs. France / Saramati vs. France, Germany \& Norway. Casos no. 71412/01 e 78166/01. Julgado em 02 mai. 2007.

.Stichting Mothers of Srebrenica and Others v. the Netherlands. Caso no. 65542/12. Julgado em 11 jun. 2013.

Waite and Kennedy v. Germany. Caso no. 26083/94. Julgado em 18 fev. 1999.

EVANS, Malcolm D. Internacional Law. 4ª ed. Oxford: Oxford University Press, 2014.

FADISMA. Denúncia à Comissão Interamericana de Direitos Humanos. Out. 2011. Disponível em: 〈http://s.conjur.com.br/dl/haiti-denuncia-onu-oea.pdf〉. Acesso em 13 ago. 2015.

FOX, Hazel; WEBB, Philippa. The Law of State Immunity. $3^{\text {a }}$ ed. Oxford: Oxford University Press, 2013.

GAILLARD, Emmanuel; PINGEL-LENUZZA; Isabelle. International Organizations and Immunity from Jurisdiction. International \& Comparative Law Quarterly. Oxford, v. 51, n. 1, pp. 1-15, 2002.

HERZ, Monica; HOFFMAN, Andrea Ribeiro. Organizações Internacionais: história e práticas. Rio de Janeiro: Elsevier, 2004.

HIGGINS, Rosalyn. Problems and Process: international law and how we use it. New York: Oxford University Press, 1994.

HUNTER, David B. International Financial Institutions and International Law. Hague: Kluwer, 2010.

INTERNATIONAL COURT OF JUSTICE - ICJ. Applicability of Article VI, Section 22, of the Convention on the Privileges and Immunities of the United Nations. Advisory Opinion publicada em 15 dez. 1989, pp. 195-196. Disponível em: <http://www.icjcij.org/docket/index.php?sum $=415 \& \operatorname{code}=\mathrm{ecos} \quad$ oc\&p1 $=3 \& \mathrm{p} 2=4 \& \quad$ case $=81 \& \mathrm{k}=48$ \&p3 $=5 \% \mathrm{E} 3 \% 80 \% 88=\mathrm{fr}>$. Acesso em 10 ago. 2015. 
.Applicability of the Obligation to Arbitrate under Section 21 of the United Nations Headquarters Agreement of 26 June 1947. Advisory Opinion publicada em 26 abr. 1988. Disponível em: <http://www.icj-cij.org/doc ket/files/77/6729.pdf>. Acesso em 15 ago. 2015.

.Certain Expenses of the United Nations (Article 17, paragraph 2, of the Charter). Advisory Opinion publicada em 20 jul. 1962. Disponível em: <www.icjcij.org/docket/files/49/5259.pdf>. Acesso em 16 ago. 2015.

Difference relating to immunity from legal process of a Special Rapporteur of the Commission on Human Rights. Advisory Opinion publicada em 29 abr. 1999. Disponível em: <http://www.icj-cij.org/docket/fi les/100/7621.pdf>. Acesso em 10 ago. 2015

Effect of Awards of Compensation Made by the United Nations Administrative Tribunal. Advisory Opinion publicada em 21 dez. 1953. Disponível em: $<w w w . i c j-c i j . o r g /$ docket/index.php?p1=3\&p2=4\&code=unac\&ca $\quad$ se=21\&k=d2\&p3=0>. Acesso em 15 ago. 2015.

.Interpretation of the Agreement of 25 March 1951 between the WHO and Egypt. Advisory Opinion publicada em 20 dez. 1980. Disponível em: <http://www.icjcij.org/docket/files/65/6303.pdf>. Acesso em 12 ago. 2015.

.Legality of the Use by a State of Nuclear Weapons in Armed Conflict. Advisory Opinion publicada em 08 jul. 1996. Disponível em: <http://www.icjcij.org/docket/files/93/7407.pdf>. Acesso em 10 ago. 2015.

.Reparation for Injuries Suffered in the Service of the United Nations. Advisory Opinion publicada em 11 abr. 1949. Disponível em: <www.icjcij.org/docket/index.php?p1=3\&p2=4\&case=4\&p3=4>. Acesso em 08 ago. 2015.

LIMA, Sergio Eduardo M. Imunidade Diplomática: instrumento de Política Externa. Rio de Janeiro: Lumen Juris, 2004.

MARTHA, Rutsel Silvestre J. Internacional Financial Institutions and Claims of Private Parties: immunities obliges. In: CISSÉ, Hassane; BRADLOW, Daniel D.; KINGSBURY, Benedict. The World Bank Legal Review. Vol. 3. Washington D.C.: IBRD, 2012.

MELlO, Celso D. de Albuquerque. Curso de Direito Internacional Público. $4^{\mathrm{a}}$ ed. Rio de Janeiro: Freitas Bastos, 1974. 
.Responsabilidade Internacional do Estado. Rio de Janeiro: Renovar, 1995.

MERCOSUL. Decisão do Conselho Mercado Comum n. 4. 1996.

.Protocolo de Ouro Preto. 1994.

O'CONNELL, Mary Ellen. The Role of Soft Law in a Global Order. In: SHELTON, Dinah (Ed.). Commitment and Compliance: The Role of Non-Binding Norms in the International Legal System. New York: Oxford University Press, 2003.

ORGANIZAÇÃO DOS ESTADOS AMERICANOS - OEA. Carta da Organização dos Estados Americanos. 1948.

. Convenção Americana sobre Direitos Humanos. 1969.

ORGANIZAÇÃO DAS NAÇÕES UNIDAS - ONU. Carta das Nações Unidas. 1945.

. Convenção da ONU sobre o Direito do Mar. 1982.

.Convenção de Viena sobre Relações Diplomáticas. 1961.

. Convenção sobre Privilégios e Imunidades das Agências Especializadas das Nações Unidas. 1947.

.Convenção sobre Privilégios e Imunidades das Nações Unidas. 1946.

. Draft Articles on the Responsibility of States for Internationally Wrongful Acts. 2001.

Draft Articles on the Responsibility of International Organizations. 2011.

.Estatuto da Corte Internacional de Justiça. 1945.

Agreement between the United Nations and the United States of America regarding the Headquarters of the United Nations. 1947. Disponível em: <https://treaties.un.org/doc/publication/UNTS/Volume\%2011/v 11.pdf>. Acesso em 10 ago. 2015.

PERMANENT COURT OF ARBITRATION - PCA. Multilateral Treaties. s/d. Disponível em: <http://www.pca-cpa.org/showpage890a.html?pag_id=1389>. Acesso em 13 ago. 2015. 
.Other Agreements and Instruments. s/d. Disponível em: <http://www.pcacpa.org/showpage31a4.html?pag_id=1390>. Acesso em 13 ago. 2015.

PERMANENT COURT OF INTERNATIONAL JUSTICE - PCIJ. Factory of Chorzow (Germany vs. Poland). Jurisdiction. Julgado em 26 de julho de 1927. Disponível em: <http://www.icj-cij.org/pcij/serie_A/A_09/28_Usine_de_Chor zow_Competence_Arret.pdf>. Acesso em 12 ago. 2015.

.Jurisdiction of the European Commission of the Danube. Advisory Opinion publicada em 08 dez. 1927. Disponível em: <http://www.icjcij.org/pcij/serie_B/B_14/01_Commission_europeenne_du_Danube_Avis_consultatif.pdf $>$. Acesso em 15 ago. 2015.

PELLET, Alain. International Organizations are definitely not States. In: RAGAZZI, Maurizio. Responsability of Internacional Organizations. Hague: Martinus Nijhoff Pub., 2013.

PORTELA, Paulo Henrique G. Direito Internacional Público e Privado. $4^{\mathrm{a}}$ ed. Salvador: Juspodivm, 2012.

RATNER, Steven R. International Tin Council v. Amalgamet Inc. 524 N.Y.S.2d 971. American Journal of International Law. Washington D.C., v. 82, n. 4, pp. 837-840, out. 1988.

REINISCH, August. International Organizations before National Courts. Cambridge: Cambridge University Press, 2004.

. The immunity of international organizations and the jurisdiction of their administrative tribunals. Chinese Journal of International Law. Oxford, v. 7, n. 2, pp. 285306, 2008.

The Privileges and Immunities of International Organizations in Domestic Courts. Oxford: Oxford University Press, 2013.

; WEBER, Ulf Andreas. In The Shadow of Waite And Kennedy: the jurisdictional immunity of international organizations, the individual's right of access to the courts and administrative tribunals as alternative means of dispute settlement. International Organizations Law Review. Leiden, n.1, pp. 59-110, 2004.

REZEK, José Francisco. Direito Internacional Público: curso elementar. 9a ed. São Paulo: Saraiva, 2002. 
SANDS, Philippe; KLEIN, Pierre. Bowett's Law of International Institutions. $6^{\text {a }}$ ed. London: Street \& Maxwell, 2009.

SEITENFUS, Ricardo. Manual das Organizações Internacionais. Porto Alegre: Livraria do Advogado, 2000.

SHAW, Malcolm N. International Law. $5^{\text {a }}$ ed. Cambridge: Cambridge University Press, 2003.

SHMALENBACH, Kirsten. Third Party Liability of International Organizations. In: LANGHOLTZ, Harvey; KONDOCH, Boris; WELLS, Alan. International Peacekeeping: the yearbook of international peace operations. Vol. 10. Hague: Martinus Nijhoff Pub., 2006. SIMMONDS, R. Legal problems arising from the United Nations military operations in the Congo. Hague: Martinus Nijhoff Pub., 1968.

SMOUTS, Marie-Claude. A cooperação internacional: da coexistência à governança mundial. In: SMOUTS, Marie-Claude (org.). As Novas Relações Internacionais: práticas e teorias. Brasília: Ed. Universidade de Brasília, 2004.

SOARES, Guido Fernando. Das Imunidades de Jurisdição e de Execução. Rio de Janeiro: Forense, 1984.

SUPREMO TRIBUNAL FEDERAL - STF. Apelação Cível n. 9696-3/SP. Rel. Min. Sydney Sanches. Julgado em 31 mai. 1989 - Pleno. Publicado no DJ em 12 out. 1990.

.Recurso Extraordinário n. 578543/MT. Rel. Min. Ellen Gracie. Julgado em 15 mai. 2013 - Tribunal Pleno. Publicado no DJe em 26 mai. 2014.

SUPERIOR TRIBUNAL DE JUSTIÇA - STJ. Recurso Especial n. 1.159.379/DF. Registro n. 2009/0194481-9. Relator Min. Teori Albino Zavascki, Julgado em 08 jun. 2011 - $1^{\text {a }}$ seção, Publicado no DJe em 27 jun. 2011.

TRIBUNAL ARBITRAL DA ONU. Teixeira v. Secretário-Geral da ONU. Julgamento n. 230 de 14 out. $1977 . \quad$ Disponível em: <http://untreaty.un.org/UNAT/UNAT_Judgements/Judgements_E/UNAT_00230_E.pdf>. Acesso em 15 ago. 2008.

TRIBUNAL DE GRANDE INSTANCE DE PARIS. UNESCO v. Boulois. Revue de l'arbitrage. Paris, 1999.

TRIBUNAL SUPERIOR DO TRABALHO - TST. Agravo em Recurso de Revista n. 2718000320045020061. Rel. Min. Augusto César Leite de Carvalho. Julgado em 24 jun. 2015 - $6^{\mathrm{a}}$ Turma. Publicado no DEJT em 25 jun. 2015. 
UN OFFICE OF LEGAL AFFAIRS. Memorandum to the Legal Adviser - UNRWA. United Nations Juridical Yearbook. Nova York, part II, pp.157-193, 1984.

.The UN as amicus curiae in Marvin R. Broadbent et al. $v$. OAS. United Nations

Juridical Yearbook. Nova York, part III, pp. 220-242, 1980.

UNASUL. Tratado Constitutivo da União de Nações Sul-Americanas. 2008.

UN ECONOMIC, SOCIAL AND CULTURAL ORGANIZATION - UNESCO. Agreement between France and UNESCO regarding its Headquarters and the Privileges and Immunities of the Organization on French Territory. 1954.

UNIÃO EUROPEIA. Convenção Europeia de Direitos Humanos. 1950.

.Tratado de Lisboa. 2007.

VARELLA, Marcelo Dias. Direito Internacional Público. $3^{a}$ ed. São Paulo: Saraiva, 2011.

VELASCO, Manuel Diez. Las Organizaciones Internacionaels. Madrid: Tecnos, 1999.

VERDROSS, Alfred. Derecho Internacional Público. 4ª ed. Madrid: Aguilar, 1963.

YOUNG, Aron L. Deconstructing International Organization Immunity. Georgetown Journal of International Law. Washington D.C., v. 44, pp. 311-364, 2012. 